Supporting Information

\title{
Reducibility and Dispersion Influence the Activity in Silica-Supported Vanadium-Based Catalysts for the Oxidative Dehydrogenation of Propane: the Case of Sodium Decavanadate
}

Manouchehr Nadjafi, ${ }^{+}$Paula M. Abdala, ${ }^{\dagger}$ Rene Verel, ${ }^{\dagger}$ Davood Hosseini, ${ }^{\dagger}$ Olga V. Safonova,,${ }^{\circledR}$ Alexey Fedorov, ${ }^{*+}$ and Christoph R. Müller ${ }^{*+}$

\footnotetext{
${ }^{\dagger}$ Laboratory of Energy Science and Engineering, Institute of Energy Technology, Department of Mechanical and Process Engineering, Leonhardstrasse 21, CH-8092 Zurich, Switzerland

${ }^{\ddagger}$ Laboratory of Inorganic Chemistry, Department of Chemistry and Applied Biosciences, ETH Zürich, Vladimir-Prelog-Weg 1-5, CH-8093 Zürich Switzerland

${ }^{\circledR}$ Division of Energy and Environment, Paul Scherrer Institute, CH-5232 Villigen, Switzerland
}

*E-mails:

fedoroal@ethz.ch (A.F.)

muelchri@ethz.ch (C.R.M.) 


\section{Table of Contents}

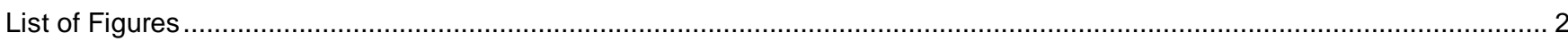

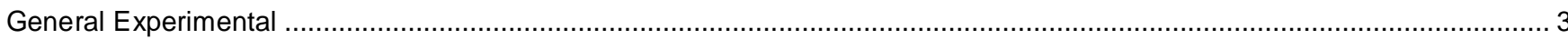

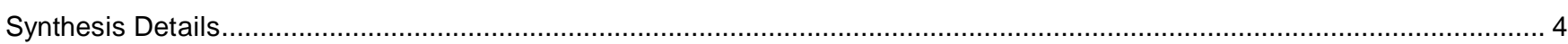

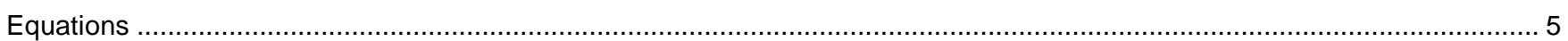

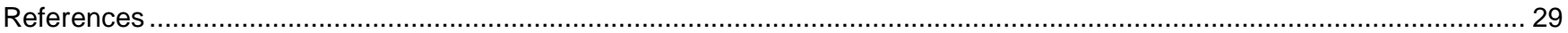

\section{List of Figures}

Figure S1. The thermal transformation of $\beta-\mathrm{NaVO}_{3}$ to $\alpha-\mathrm{NaVO}_{3}$ followed by in situ Raman spectroscopy................................................... 6

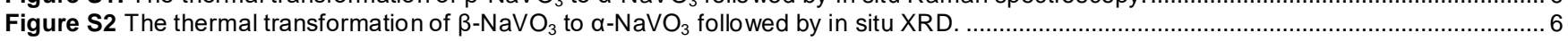

Figure S3. Full range Raman spectra of calcined in air, dehydrated and $\mathrm{N}_{2}$-treated $\mathrm{Na}_{6} \mathrm{~V}_{10} \mathrm{O}_{28} / \mathrm{SiO}_{2}$ along with the respective references........ 7

Figure S4. ${ }^{11} \mathrm{~V}$ MAS NMR spectra of $\mathrm{Na}_{6} \mathrm{~V}_{10} \mathrm{O}_{28} / \mathrm{SiO}_{2}$ (exposed to air after calcination) along with reference materials. ................................. 7

Figure S5. Dependence of pre-edge peak height and energy position on the $\mathrm{V}$ coordination geometry............................................................. 8

Figure S6. V K-edge XANES linear combination fitting (LCF) of $\mathrm{Na}_{6} \mathrm{~V}_{10} \mathrm{O}_{28} / \mathrm{SiO}_{2}$ using $\beta-\mathrm{NaVO}_{3}$ and $\mathrm{Na}_{1+\times} \mathrm{V}_{3} \mathrm{O}_{8} / \mathrm{SiO}$ as reference materials... 8

Figure S7. Na K-edge XANES linear combination fitting (LCF) of $\mathrm{Na}_{6} \mathrm{~V}_{10} \mathrm{O}_{28} / \mathrm{SiO}_{2}$ using $\beta-\mathrm{NaVO}_{3}$ and $\mathrm{Na}_{1+\times} \mathrm{V}_{3} \mathrm{O}_{8} / \mathrm{SiO}_{2}$ as reference materials. 9

Figure S8. Raman spectra of $\alpha-\mathrm{NaVO}_{3} / \mathrm{SiO}_{2}$ before and after calcination (followed by $\mathrm{N}_{2}$ or air treatment). Surface structures do not change

after air or $\mathrm{N}_{2}$ treatment.

Figure S9. Calcination of $\mathrm{Na}_{6} \mathrm{~V}_{10} \mathrm{O}_{28} \cdot 18 \mathrm{H}_{2} \mathrm{O}\left(30 \mathrm{ml} \mathrm{min}{ }^{-1}\right.$, air $)$ followed by in situ XRD.

Figure S10. Diffractograms of reference materials and $\mathrm{Na}_{6} \mathrm{~V}_{10} \mathrm{O}_{28} \cdot 18 \mathrm{H}_{2} \mathrm{O}$ heated up to $350{ }^{\circ} \mathrm{C}\left(30 \mathrm{ml} \mathrm{min}{ }^{-1}\right.$, air $)$......................................10

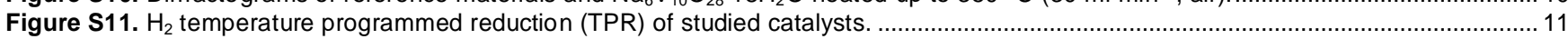

Figure S12. ${ }^{51} \mathrm{~V}$ MAS NMR spectra of $\mathrm{Na}_{6} \mathrm{~V}_{10} \mathrm{O}_{28} / \mathrm{SiO}_{2}$ after $4 \mathrm{~h} \mathrm{TOS}, \mathrm{N}_{2}$ or air pre-treatment $\left(450{ }^{\circ} \mathrm{C}, 1 \mathrm{~h}\right)$ along with references.................. 11

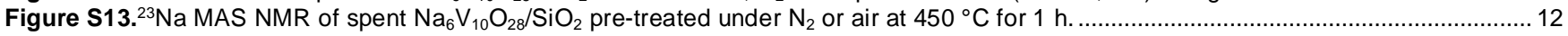

Figure S14. Catalytic data of the $\mathrm{Na}_{6} \mathrm{~V}_{10} \mathrm{O}_{28} / \mathrm{SiO}_{2(450 \text {-air) }}$ and $\mathrm{Na}_{6} \mathrm{~V}_{10} \mathrm{O}_{28} / \mathrm{SiO}_{2(450-\mathrm{N} 2)}$ treated under air for 60 min before reactants introduction. .. 12

Figure S15. Raman spectra of $\mathrm{Na}_{6} \mathrm{~V}_{10} \mathrm{O}_{28} / \mathrm{SiO}_{2(450-\mathrm{N} 2)}$ after $30 \mathrm{~min}$ and 60 min exposure to air at $450{ }^{\circ} \mathrm{C}$. All spectra are collected at room

temperature under $\mathrm{N}_{2}$ atmosphere after high temperature treatment using $\mathrm{N}_{2}$ or air. .

Figure S16. Propene selectivity vs TOS for $\left[\mathrm{VO}_{4}\right] / \mathrm{SiO}_{2}$ catalyst treated under air or $\mathrm{N}_{2}$ for $1 \mathrm{~h}$ at $450{ }^{\circ} \mathrm{C}$

Figure S17. Propene selectivity vs TOS for $\alpha-\mathrm{NaVO}_{3} / \mathrm{SiO}_{2}$ (prepared from $\beta-\mathrm{NaVO}_{3}$ precursor, calcined at $600{ }^{\circ} \mathrm{C}, \sim 1 \mathrm{~V} \mathrm{~nm}{ }^{-1}$ ) catalyst, treated

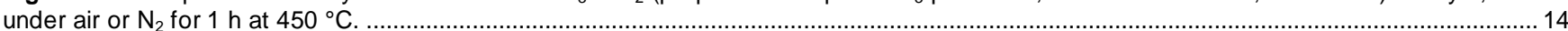

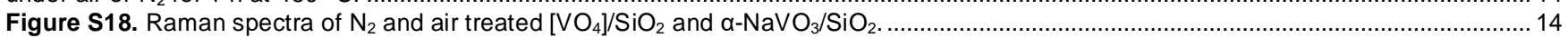

Figure S19. Composition of the effluent during the operando XANES ODP experiment with $\mathrm{Na}_{6} \mathrm{~V}_{10} \mathrm{O}_{28} / \mathrm{SiO}_{2(450-\mathrm{N} 2)}$........................................... 15

Figure S20. Selected area electron diffraction (SAED) of a nanorod in $\mathrm{Na}_{6} \mathrm{~V}_{10} \mathrm{O}_{28} / \mathrm{SiO}_{2(450-\mathrm{N} 2)}$ after 12 min TOS under ODP conditions (WHSV

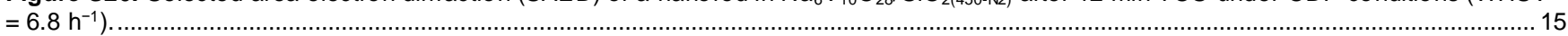

Figure S21. Propylene selectivity and productivity vs. propane conversion at different temperatures for air treated $(1 \mathrm{~h}$ at designated

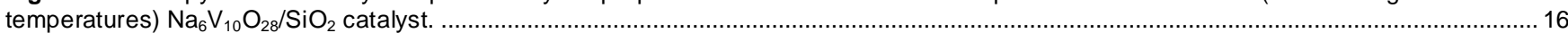

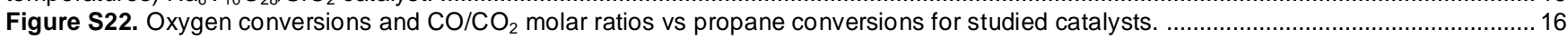

Figure S23. Oxygen conversions and $\mathrm{CO} / \mathrm{CO}_{2}$ molar ratios vs. propane conversions at different temperatures for air treated $(1 \mathrm{~h}$ at

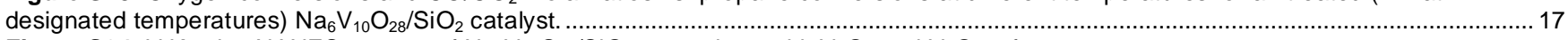

Figure S24. $\mathrm{V}$ K-edge XANES spectra of $\mathrm{Na}_{6} \mathrm{~V}_{10} \mathrm{O}_{28} / \mathrm{SiO}_{2(500-\mathrm{N} 2)}$ along with $\mathrm{V}_{2} \mathrm{O}_{4}$ and $\mathrm{V}_{2} \mathrm{O}_{5}$ references. ...............................................17

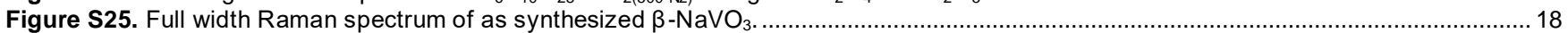

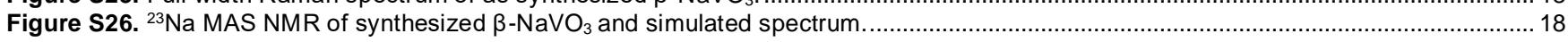

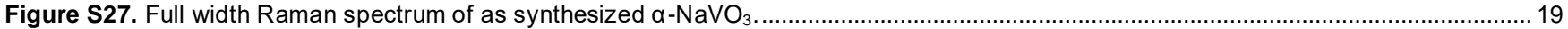

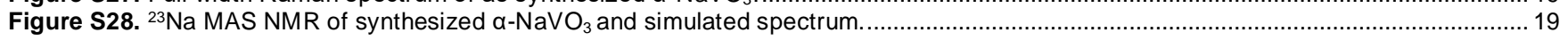

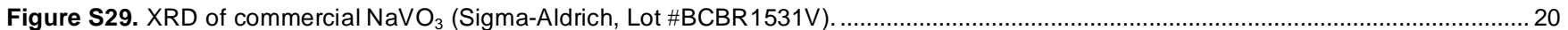

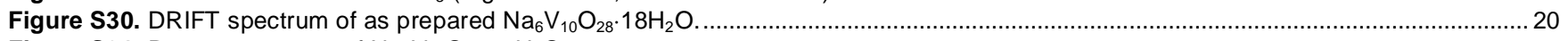

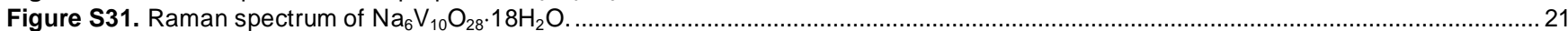

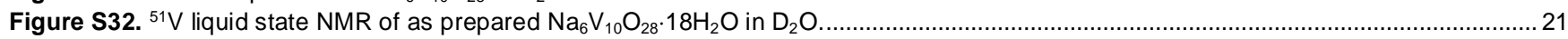

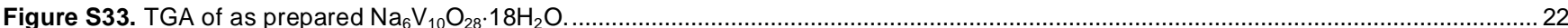

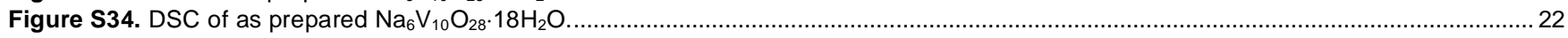

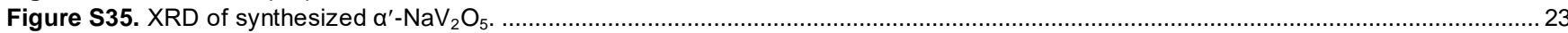

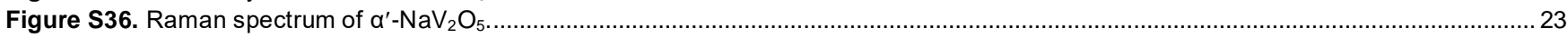

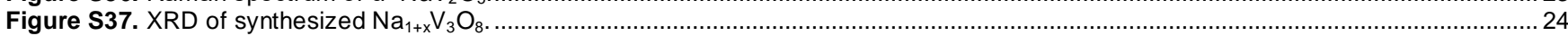

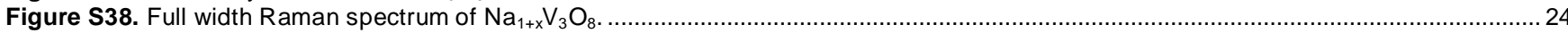

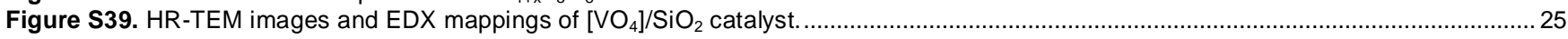

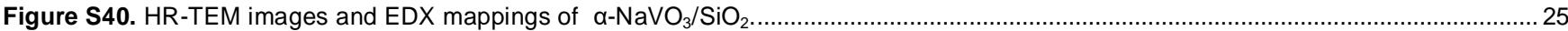

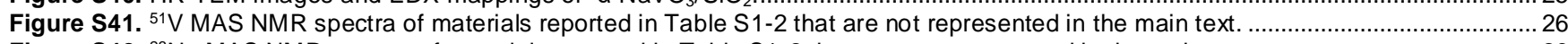

Figure S42. ${ }^{23} \mathrm{Na}$ MAS NMR spectra of materials reported in Table S1-2 that are not represented in the main text..................................... 26 


\section{General Experimental}

Sodium metavanadate ( $\geq 99.9 \%$, Sigma-Aldrich, Lot \#BCBR1531V), ammonium metavanadate ( $\geq 99 \%$, Acros Organics, Lot \#447261000), oxalic acid dihydrate ( $\geq 99.0$, Fisher Scientific), Aerosil 300 ( $\geq 99.8 \%$, Evonik, $S_{B E T}=300 \pm 30 \mathrm{~m}^{2} \mathrm{~g}^{-1}, \mathrm{~V}_{\text {pore }}=0.56 \mathrm{ml} \mathrm{g}$ ), silicon carbide ( $\geq 98.8 \%$, Alfa Aesar), hydrochloric acid (37\%, Sigma-Aldrich), vanadium (V) oxide ( $\geq 98 \%$, Sigma-Aldrich, Lot \#MKBW3222V), vanadium (IV) oxide ( $\geq 99.0 \%$, Strem Chemicals), vanadium (III) oxide ( $\geq 98.0 \%$, Sigma-Aldrich), sodium orthovanadate ( $\geq 99.0 \%$, Acros Organics) sodium hydroxide (certified AR for analysis, Fischer Scientific), sodium oxalate ( $\geq 99.5 \%$, Sigma-Aldrich), and sodium nitrate-( $\geq 99 \%$, Acros Organics) were obtained from the respective vendor and used as received.

Nitrogen physisorption was performed on a NOVA 4000 e (Quantachrome) instrument at $-196{ }^{\circ} \mathrm{C}$. Prior to the experiment, the samples were degassed at $300{ }^{\circ} \mathrm{C}$ for $3 \mathrm{~h}$. The specific surface area and pore volume were calculated using the Brunauer-Emmett-Teller (BET) ${ }^{[1]}$ and Barrett-Joyner-Halenda (BJH) models, ${ }^{[2]}$ respectively.

$\mathrm{X}$-ray powder diffraction (XRD) data were collected on a Panalytical Empyrean diffractometer using Cu $\mathrm{K}_{\alpha}$ radiation, operated at $45 \mathrm{kV}$ and $40 \mathrm{~mA}$ and equipped with a $X^{\prime}$ Celerator Scientific ultra-fast line detector and a Bragg-Brentano HD incident beam optics. The scans were performed in the $2 \theta$ range of $5^{\circ}-100^{\circ}$ with a step size of $0.017^{\circ}$ and a collection time of $0.65 \mathrm{~s}$ per step. An Anton Paar cell was used for in situ measurements.

Scanning transmission electron microscopy data and elemental maps (TEM-EDX) were acquired on an FEI Talos F200X electron microscope $(200 \mathrm{kV})$. The microscope was equipped with a high brightness Schottky FEG and a Super-X integrated EDS system, which includes four silicon drift detectors (SDDs) placed symmetrically around the sample.

Diffuse Reflectance Infrared Fourier Transform (DRIFT) spectroscopy measurements were conducted in a Praying Mantis diffuse reflectance accessory using a Nicolet $6700 \mathrm{FT}-\mathrm{IR}$ spectrophotometer with 32 scans at a resolution of $8 \mathrm{~cm}^{-1}$.

Raman measurements were carried out with a DXR 2 Raman spectrometer (Thermo Fisher) using a $455 \mathrm{~nm}$ excitation laser with an estimated spot size of $2.1 \mu \mathrm{m}$. For dehydration, samples were pre-treated in a high-temperature Linkam CCR 1000 cell at $500^{\circ} \mathrm{C}\left(10^{\circ} \mathrm{C}\right.$ $\mathrm{min}^{-1}$ ) for $1 \mathrm{~h}$ under $30 \mathrm{ml} \mathrm{min}^{-1}$ air and cooled down to room temperature under nitrogen (gases were switched always below $250{ }^{\circ} \mathrm{C}$ ). All measurements were done at room temperature under flowing nitrogen using a full range grating with a resolution of 1200 lines mm $^{-1}$ in a range of 106-3500 $\mathrm{cm}^{-1}$. In general, 10 different areas of a specimen were measured and averaged to ensure reproducibility of the data. Notations used are as follows: $v_{a s}$ is an asymmetric stretching mode, $v_{s}$ is a symmetric stretching mode, and $\delta$ is a bending mode.

Inductively coupled plasma optical emission spectroscopy (ICP-OES) was performed on an Agilent 5100 VDV instrument. The multielement standard 5 (Sigma Aldrich) was used for calibration. Samples were prepared by digesting $\sim 3 \mathrm{mg}$ of the specimen in $4 \mathrm{ml} \mathrm{HNO}_{3}$. The resulting solutions were diluted with de-ionized (DI) water to $25 \mathrm{ml}$. To avoid any contamination, trace-grade acid and $\mathrm{HNO}_{3}$ leached glass ware were used.

Solid-state ${ }^{23} \mathrm{Na}$ and ${ }^{51} \mathrm{~V}$ NMR spectra (ss-NMR) were acquired on an Avance III HD NMR spectrometer (Bruker) operating at a ${ }^{1} \mathrm{H}$ Larmor frequency of $400 \mathrm{MHz}$. The samples were spun around the magic angle with a rate of $15-18 \mathrm{kHz}$ at room temperature using $\mathrm{N}_{2}(\mathrm{~g})$ for the drive, bearing and VT flow. A double resonance $3.2 \mathrm{~mm}$ probe was tuned to $105.27 \mathrm{MHz}$ for the ${ }^{51} \mathrm{~V}$ experiments and 105.86 for ${ }^{23} \mathrm{Na}$, respectively. The ppm scale of the spectra was calibrated using the ${ }^{13} \mathrm{C}$ signal of adamantane as an external secondary reference. All samples were dehydrated at $500{ }^{\circ} \mathrm{C}$ for $1 \mathrm{~h}$ in a fixed bed quartz reactor under air $\left(30 \mathrm{ml} \mathrm{min}^{-1}\right)$, then cooled down and the gas exchanged (below $250^{\circ} \mathrm{C}$ ) to nitrogen $\left(30 \mathrm{ml} \mathrm{min}^{-1}\right)$. Samples were packed into rotors inside a nitrogen-filled glovebox $(<1 \mathrm{ppm}$ of $\mathrm{O}_{2}$ and $\mathrm{H}_{2} \mathrm{O}$ ). The rotor contained ca. $80 \mathrm{mg}$ of a specimen.

X-ray absorption spectroscopy (XAS) data at the V K-edge was collected at the SuperXAS beamline at Swiss Light Source (SLS) in both fluorescence and transmission modes, depending on the vanadium content of the samples. In the case of silica-supported materials, the measurements were done in the florescence mode while for pure vanadates the transmission mode was used. One scan was recorded for each sample. Dehydroxylated samples were pelletized and sealed in aluminum bags (for transmission mode measurement) or filled in capillaries and sealed with vacuum grease and paraffin (for florescence mode measurement). Na K-edge XAS measurements were carried out at the Phoenix II beamline (SLS) using indium for sample fixation and a copper plate as a sample holder. A fluorescence detector (Vortex four-element Si-drift diode detector) and total electron yield signal were used to collect the XAS data. The software Athena was used to process the data. ${ }^{[3]}$

Melting point measurements, and crystalline water calculation experiments were performed in a thermogravimetric analyzer/differential scanning calorimeter (TGA/DSC, Mettler Toledo).

Temperature programmed reduction (TPR) experiments were conducted in a commercial BELCAT-M TPX instrument. Each catalyst (50 mg) was fixed in a quartz tube using quartz wool. All catalyst were pre-treated at $300{ }^{\circ} \mathrm{C}$ for one hour using $50 \mathrm{ml} \mathrm{min}^{-1} \mathrm{Ar}$ and cooled down to $100{ }^{\circ} \mathrm{C}$. $\mathrm{H}_{2}$ TPR was then performed using $5 \% \mathrm{H}_{2}$ in $\operatorname{Ar}\left(50 \mathrm{~mL} \mathrm{~min}^{-1}, 10^{\circ} \mathrm{C} \mathrm{min}{ }^{-1}\right.$ ) while recording the TCD signal up to $750^{\circ} \mathrm{C}$.

The crystalline water content of as prepared $\mathrm{Na}_{6} \mathrm{~V}_{10} \mathrm{O}_{28}$. (hydrate) was determined by the weight loss of the material (10 mg) heated in an alumina crucible to $300{ }^{\circ} \mathrm{C}\left(10^{\circ} \mathrm{C} \mathrm{min}{ }^{-1}\right)$ under a flow of $\mathrm{O}_{2}$ in $\mathrm{N}_{2}\left(5\right.$ vol. \%, total flow $\left.100 \mathrm{~mL} \mathrm{~min}^{-1}\right)$ and kept at this temperature for $1 \mathrm{~h}$. The melting point was determined by heating a specimen $(10 \mathrm{mg})$ in a platinum crucible to $700{ }^{\circ} \mathrm{C}\left(10^{\circ} \mathrm{C}\right.$ min $\left.^{-1}\right)$ under a flow of $\mathrm{O}_{2}$ in $\mathrm{N}_{2}\left(5\right.$ vol.\%, total flow $\left.100 \mathrm{~mL} \mathrm{~min}{ }^{-1}\right)$. After holding at this temperature for $1 \mathrm{~h}$, the specimen was cooled down to room temperature under the same conditions. The melting point is determined from the DSC curve as the intersection point of two tangential lines to the negative peak of the baseline. 
Catalytic tests were performed in a PID Microactivity-Efficient reactor. A total amount of $100 \mathrm{mg}$ of catalyst (150-300 $\mu \mathrm{m})$ was mixed with $200 \mathrm{mg}$ of inert coarse $\mathrm{SiC}, 46$ grit particles and packed in a quartz reactor tube (10 mm internal diameter). Reactions were carried out at $450{ }^{\circ} \mathrm{C}$ with inlet flow ratios of $3: 6: 12$ of $\mathrm{O}_{2} / \mathrm{C}_{3} \mathrm{H}_{8} / \mathrm{N}_{2}$ and a total flow of $21 \mathrm{ml} \mathrm{min}^{-1}$. Off-gas were analyzed using a Perkin Elmer Clarus 580 GC equipped with two Restek columns (ShinCarbon ST 80/100 and HP Plot Q) and a thermal conductivity detector (TCD), flame ionization detector (FID), and a methanizer. The carbon balance of each data point closes within $5 \%$. Catalysts were heated under nitrogen/air and when desired reaction temperature was achieved, the catalysts were pre-treated for $1 \mathrm{~h} \mathrm{more} \mathrm{under} \mathrm{N}_{2} / a$ ir and then reactants were introduced to the reactor, first data point collected after $10 \mathrm{~min}$ of reaction.

To obtain the data for propene selectivity as a function of propane conversion, the total flow of the reactants was varied between 15.8 and $42 \mathrm{ml} \mathrm{min}^{-1}$ while keeping the same propane-to-air ratio of 2 to 5 . In a typical experiment, $0.1 \mathrm{~g}$ of catalyst was heated up to $450{ }^{\circ} \mathrm{C}$ under synthetic air $\left(21^{\circ} \mathrm{C} \mathrm{min}^{-1}\right)$ and kept at this temperature for $1 \mathrm{~h}$ prior to introduction of reactants. Starting from the highest total flow (WHSV $=13.6 \mathrm{~h}^{-1}$ ) two GC data points were collected for each WHSV (ca. $30 \mathrm{~min}$ of TOS). This was followed by decreasing the flow rate to obtain additional data for WHSV $=10.2,6.8$ and $5.1 \mathrm{~h}^{-1}$.

\section{Synthesis Details}

$\beta-\mathrm{NaVO}_{3}$ was synthesized following a literature method, ${ }^{[4]}$ that is reproduced below for convenience (see Figure S25 for the Raman spectrum and Figure S26 for the ${ }^{23} \mathrm{Na}$ MAS NMR data):

$\mathrm{NH}_{4} \mathrm{VO}_{3}(5 \mathrm{~g}, 42.7 \mathrm{mmol})$ was dissolved in $500 \mathrm{ml}$ DI water at $80{ }^{\circ} \mathrm{C}$ while stirring $(\mathrm{ca} .2 \mathrm{~h})$ and then $\mathrm{NaOH}$ was added $(1.71 \mathrm{~g}$, $42.7 \mathrm{mmol}$ ). Once the evolution of ammonia ceased, the precipitate was collected by filtration and dried at $100^{\circ} \mathrm{C}$ overnight.

$\alpha-\mathrm{NaVO}_{3}$ was prepared by calcining $\beta-\mathrm{NaVO}_{3}$ at $600{ }^{\circ} \mathrm{C}$ for 4 hours in a muffle furnace (see Figure S27 for the Raman spectrum and Figure S28 for the ${ }^{23} \mathrm{Na}$ MAS NMR simulation). Subjecting $\beta-\mathrm{NaVO}_{3}$ to $403-405^{\circ} \mathrm{C}^{[4]}$ or higher temperatures ${ }^{[5]}$ transforms it to $\alpha-\mathrm{NaVO}_{3}$ (This transformation is shown using Raman spectroscopy and XRD, Figure $\mathrm{S} 1$ and $\mathrm{S} 2$, respectively).

Sodium decavanadate $\left(\mathrm{Na}_{6} \mathrm{~V}_{10} \mathrm{O}_{28} \cdot 18 \mathrm{H}_{2} \mathrm{O}\right)$ was synthesized following a literature method ${ }^{[6]}$ that is reproduced below for convenience:

Commercial $\mathrm{NaVO}_{3}(3 \mathrm{~g}, 24.6 \mathrm{mmol})$ was dissolved in de-ionized water $(100 \mathrm{~mL})$, and the $\mathrm{pH}$ was adjusted to $4.8 \mathrm{using} 4 \mathrm{M} \mathrm{HCl}$ (commercial $\mathrm{NaVO}_{3}$ was mainly $\beta-\mathrm{NaVO}_{3}$ polymorph, see Figure $\mathrm{S} 29$ for the $\mathrm{XRD}$ ). The solution was then filtered and additional $\mathrm{HCl}$ was added to maintain the $\mathrm{pH}$ at 4.5 . Subsequent addition of $96 \%$ ethanol $(200 \mathrm{~mL})$ precipitated $\mathrm{Na}_{6} \mathrm{~V}_{10} \mathrm{O}_{28} \cdot 18 \mathrm{H}_{2} \mathrm{O}$ as an orange solid, which was isolated by filtration and air-dried. ICP analysis of this material gives the molar ratio of $\mathrm{Na} / \mathrm{V}=0.596$, consistent with stoichiometric value of 0.6 of the molecular formula. DRIFT and Raman spectra (Figure S30-31) agrees with previous reports of $\mathrm{Na}_{6} \mathrm{~V}_{10} \mathrm{O}_{28} \cdot 18 \mathrm{H}_{2} \mathrm{O}$. ${ }^{[7]}{ }^{51} \mathrm{~V}$ liquid state $\mathrm{NMR}$ of as prepared $\mathrm{Na}_{6} \mathrm{~V}_{10} \mathrm{O}_{28} \cdot 18 \mathrm{H}_{2} \mathrm{O}$ in $\mathrm{D}_{2} \mathrm{O}$ (Figure S32) shows peaks at -422.2 , -497.7 , and $-513.2 \mathrm{ppm}$ attributed to the $\mathrm{C}, \mathrm{B}$, and $\mathrm{A}$ sites of the decavanadate anion, respectively. ${ }^{[6,8]}$ The combined integral of the $\left[\mathrm{V}_{10} \mathrm{O}_{28}\right]^{6-}$ anion is $>97 \%$ of the overall integral. Minor species with chemical shifts at $-558.5,-571.5$, and -575.7 ppm are monomeric $\left[\mathrm{H}_{2} \mathrm{VO}_{4}\right]^{-}$, dimeric $\left[\mathrm{HV}_{2} \mathrm{O}_{7}\right]^{3-}$ and $\left[\mathrm{H}_{2} \mathrm{~V}_{2} \mathrm{O}_{7}\right]^{2-}$, and cyclic tetrameric $\left[\mathrm{V}_{4} \mathrm{O}_{12}\right]^{4-}$ species, respectively, which are in equilibrium with the decavanadate anion in $\mathrm{D}_{2} \mathrm{O}$ solution. ${ }^{[9]}$ Thermogravimetric analysis (TGA) of $\mathrm{Na}_{6} \mathrm{~V}_{10} \mathrm{O}_{28} \cdot 18 \mathrm{H}_{2} \mathrm{O}$ gives a value of 18.3 for the number of water molecules (rounded to 18 for brevity, Figure S33). Differential scanning calorimetry (DSC) measurement of $\mathrm{Na}_{6} \mathrm{~V}_{10} \mathrm{O}_{28} \cdot 18 \mathrm{H}_{2} \mathrm{O}$ gives a $579{ }^{\circ} \mathrm{C}$ for the melting point (Figure S34).

$\alpha^{\prime}-\mathrm{NaV}_{2} \mathrm{O}_{5}$ was synthesized following the literature method ${ }^{[10]}$ that is reproduced below for convenience:

For the synthesis of $\alpha^{\prime}-\mathrm{NaV}_{2} \mathrm{O}_{5}$; typically, $\mathrm{V}_{2} \mathrm{O}_{5}(0.9094 \mathrm{~g})$ was added to $50 \mathrm{ml}$ aqueous solution of $\mathrm{Na}_{2} \mathrm{C}_{2} \mathrm{O}_{4}(0.1 \mathrm{M})$, the reaction mixture was stirred at $50{ }^{\circ} \mathrm{C}$ for $30 \mathrm{~min}$, transferred to a $80 \mathrm{ml}$ Teflon-lined autoclave and heated to $180{ }^{\circ} \mathrm{C}(19 \mathrm{~h})$. The autoclave was cooled down to room temperature overnight, the precipitate collected, washed several times with ethanol and DI water and dried under vacuum at $80{ }^{\circ} \mathrm{C}$ for $12 \mathrm{~h}$. The XRD pattern of as-prepared $\alpha^{\prime}-\mathrm{NaV}_{2} \mathrm{O}_{5}$ shows the presence of small amounts of $\mathrm{NaV}_{6} \mathrm{O}_{15}($ Figure $\mathrm{S} 35)$ and the Raman spectrum of the as synthesized material is in a good agreement with literature (Figure S36). ${ }^{[10-11]}$

$\mathrm{Na}_{1+\mathrm{x}} \mathrm{V}_{3} \mathrm{O}_{8}$ was synthesized following the literature method, ${ }^{[12]}$ that is reproduced below for convenience:

For the synthesis of $\mathrm{Na}_{1+x} \mathrm{~V}_{3} \mathrm{O}_{8}, \mathrm{~V}_{2} \mathrm{O}_{5}(2.4 \mathrm{~g}, 13.2 \mathrm{mmol})$ was mixed with oxalic acid dihydrate $(5 \mathrm{~g}, 39.6 \mathrm{mmol})$ and dissolved in $80 \mathrm{ml}$ $\mathrm{DI}$ water at $70{ }^{\circ} \mathrm{C}$ while stirring (ca. $3 \mathrm{~h}$ ) to obtain a deep navy blue solution. Then, $\mathrm{NaNO}_{3}(0.75 \mathrm{~g}, 8.8 \mathrm{mmol})$ was added at $70{ }^{\circ} \mathrm{C}$ and stirring continued for an additional hour. The solution was dried at $80^{\circ} \mathrm{C}$ overnight and the residue calcined at $400{ }^{\circ} \mathrm{C}$ for $4 \mathrm{~h}$ in a muffle furnace. The XRD pattern of $\mathrm{Na}_{1+x} \mathrm{~V}_{3} \mathrm{O}_{8}$ shows minor impurities due to a $\mathrm{NaV}_{6} \mathrm{O}_{15}$ phase (Figure S37). An analogy with the $\mathrm{Li}_{1+x} \mathrm{~V}_{3} \mathrm{O}_{8}$ iso-structure was used to assign the Raman peaks of $\mathrm{Na}_{1+x} \mathrm{~V}_{3} \mathrm{O}_{8}$ (see Figure S38). ${ }^{[13]}$

Aerosil was mixed with DI water to make a slurry. The slurry was dried overnight at $120^{\circ} \mathrm{C}$ to produce Aerosil chunks that were crushed and sieved. The fraction with 150-300 $\mu \mathrm{m}$ particle size was used for the catalyst preparation. Catalysts were prepared using incipient wetness impregnation (IWI) of aqueous solutions of $\mathrm{NaVO}_{3}(0.297 \mathrm{M}, 3.2 \mathrm{ml}), \mathrm{Na}_{6} \mathrm{~V}_{10} \mathrm{O}_{28} \cdot 18 \mathrm{H}_{2} \mathrm{O}(0.0297 \mathrm{M}, 3.2 \mathrm{ml}), \mathrm{NH}_{4} \mathrm{VO}_{3}(0.297 \mathrm{M}$, $3.2 \mathrm{ml}$ mixed with oxalic acid in a mass ration of $1: 2), \mathrm{Na}_{1+\mathrm{x}} \mathrm{V}_{3} \mathrm{O}_{8}\left(0.1 \mathrm{M}, 3.2 \mathrm{ml}\right.$ at $\left.70{ }^{\circ} \mathrm{C}\right)$ on Aerosil $300(2 \mathrm{~g})$ in air to yield materials with a nominal coverage of one $\mathrm{V}$ atom per $\mathrm{nm}^{2}$. Impregnated supports were dried at $100^{\circ} \mathrm{C}$ overnight and calcined in static air at $600{ }^{\circ} \mathrm{C}\left(4^{\circ} \mathrm{C} \mathrm{min}-1\right)$ for $4 \mathrm{~h}$. HR-TEM of catalysts made from $\mathrm{NH}_{4} \mathrm{VO}_{3}$ and $\beta-\mathrm{NaVO}_{3}$ precursors (denoted as $\left[\mathrm{VO}_{4}\right] / \mathrm{SiO}_{2}$ and a- $-\mathrm{NaVO}_{3} / \mathrm{SiO}_{2}$ ) are shown in Figure $\mathrm{S} 39$ and $\mathrm{S} 40$.

All ${ }^{51} \mathrm{~V}$ and ${ }^{23} \mathrm{Na}$ NMR results for the materials studied are provided and compared to published reports in Table S1 and S2. ${ }^{51} \mathrm{~V}$ and ${ }^{23} \mathrm{Na}$ MAS NMR of materials that are not presented in the main text are given in Figures $\mathrm{S} 41$ and S42, respectively. 


\section{Equations}

$$
\begin{aligned}
& \text { Surface density }\left(V_{\text {atoms }} \mathrm{nm}^{-2}\right)=\frac{\text { moles of vanadium } \times \text { Avogadro number } \times 10^{-18}}{\text { surface area of Aerosil }\left(\mathrm{m}^{2} \mathrm{~g}^{-1}\right) \times \text { grams of support }} \\
& \text { Selectivity to a carbon product }\left(S_{A}\right)=\frac{\text { flow of the } C \text { in a product } A\left(\mathrm{ml} \mathrm{min}{ }^{-1}\right)}{\text { total flow of the carbon in products }\left(\mathrm{ml} \mathrm{min}^{-1}\right)} \\
& \text { Propane conversion }\left(\mathrm{X}_{\mathrm{C} 3 \mathrm{H} 8}\right)=\frac{\text { total flow of the carbon in products }\left(\mathrm{ml} \mathrm{min} \mathrm{m}^{-1}\right)}{\text { total flow of the carbon in feed }\left(\mathrm{ml} \mathrm{min}^{-1}\right)}
\end{aligned}
$$

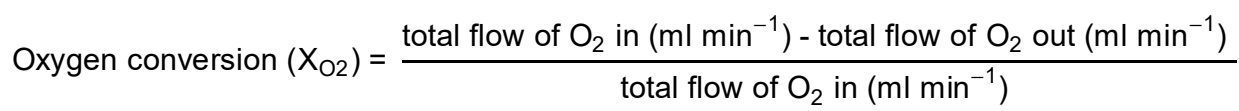

$$
\begin{aligned}
& \text { Rate } \left.=\frac{\text { flow of the desired product }\left(\mathrm{ml} \mathrm{s}^{-1}\right)}{\text { moles of } \mathrm{V} \text { catalyst } \times 24450\left(\mathrm{ml} \mathrm{mol}^{-1}\right)} \quad \text { (where } 24450 \text { is a molar volume of a gas at STP }\right) \\
& \text { WHSV }=\frac{\text { propane flow }\left(\mathrm{ml} \mathrm{h}^{-1}\right) \times \text { molecular weight of propane }\left(\mathrm{g} \mathrm{mol}^{-1}\right)}{24450\left(\mathrm{ml} \mathrm{mol}^{-1}\right) \times \text { grams of the catalyst }}
\end{aligned}
$$




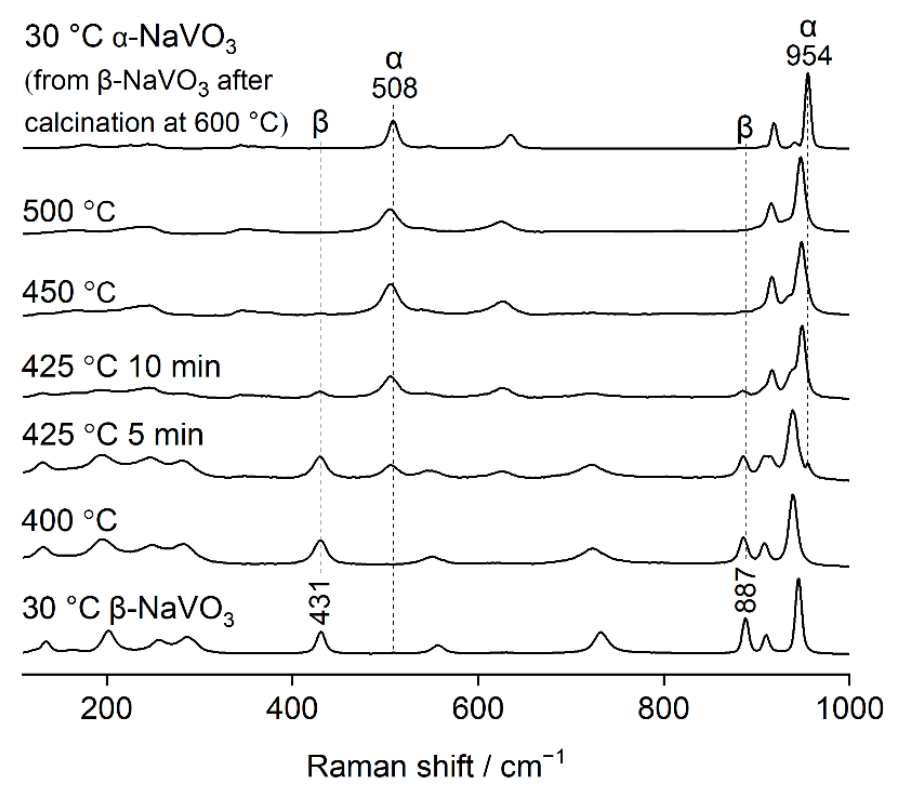

Figure S1. The thermal transformation of $\beta-\mathrm{NaVO}_{3}$ to $\alpha-\mathrm{NaVO}_{3}$ followed by in situ Raman spectroscopy.

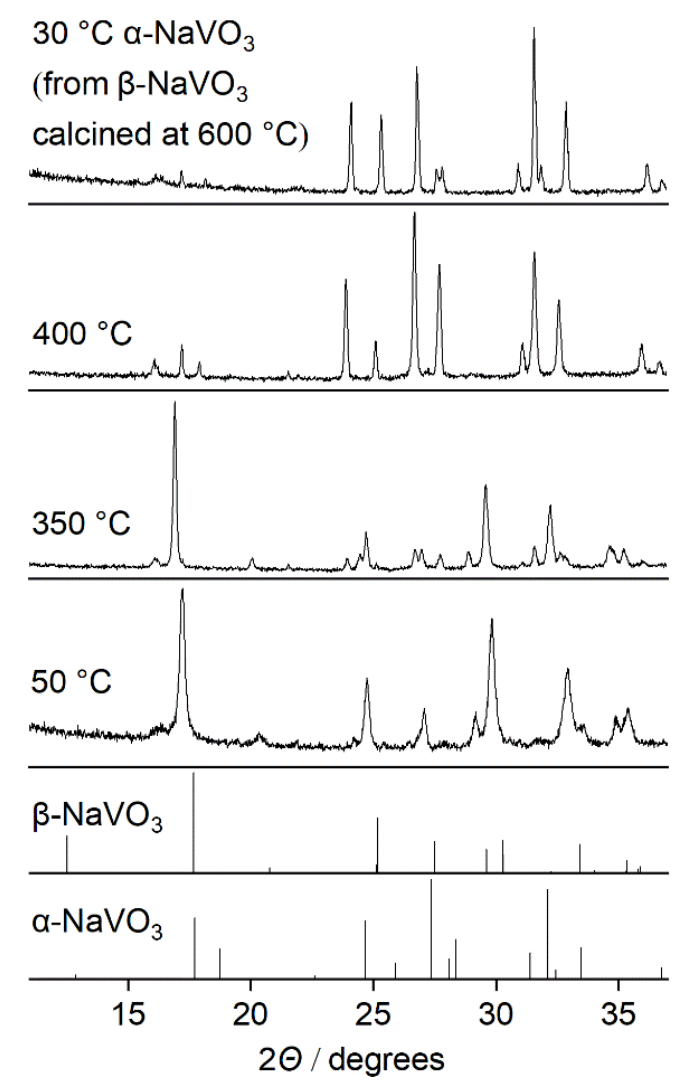

Figure S2 The thermal transformation of $\beta-\mathrm{NaVO}_{3}$ to $\alpha-\mathrm{NaVO}_{3}$ followed by in situ XRD. 


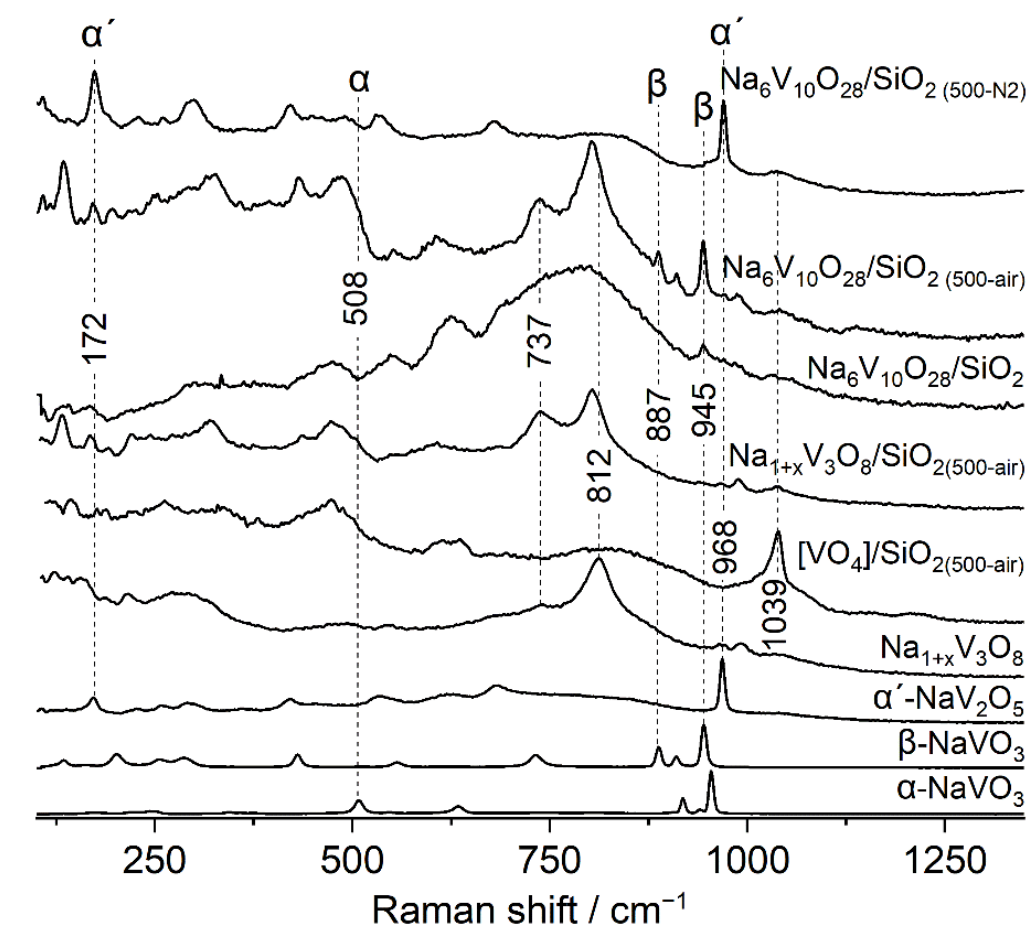

Figure S3. Full range Raman spectra of calcined in air, dehydrated and $\mathrm{N}_{2}$-treated $\mathrm{Na}_{6} \mathrm{~V}_{10} \mathrm{O}_{28} / \mathrm{SiO}$ along with the respective references.

Note that the $\beta-\mathrm{NaVO}_{3}$ and $\mathrm{Na}_{1+\mathrm{x}} \mathrm{V}_{3} \mathrm{O}_{8}$ references contain minor amounts of $\alpha-\mathrm{NaVO}_{3}$ and $\mathrm{NaV}_{10} \mathrm{O}_{15}$ impurities, respectively.

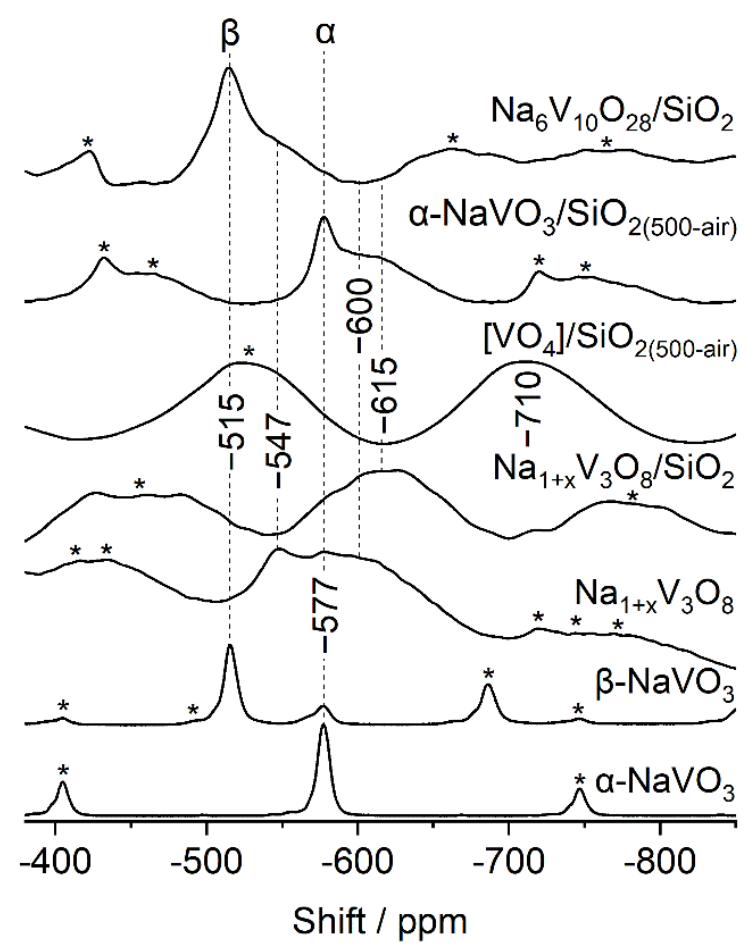

Figure S4. ${ }^{51} \mathrm{~V}$ MAS NMR spectra of $\mathrm{Na}_{6} \mathrm{~V}_{10} \mathrm{O}_{28} / \mathrm{SiO}_{2}$ (exposed to air after calcination) along with reference materials.

15-18 kHz spinning rates were used, sidebands are marked by asterisks. 


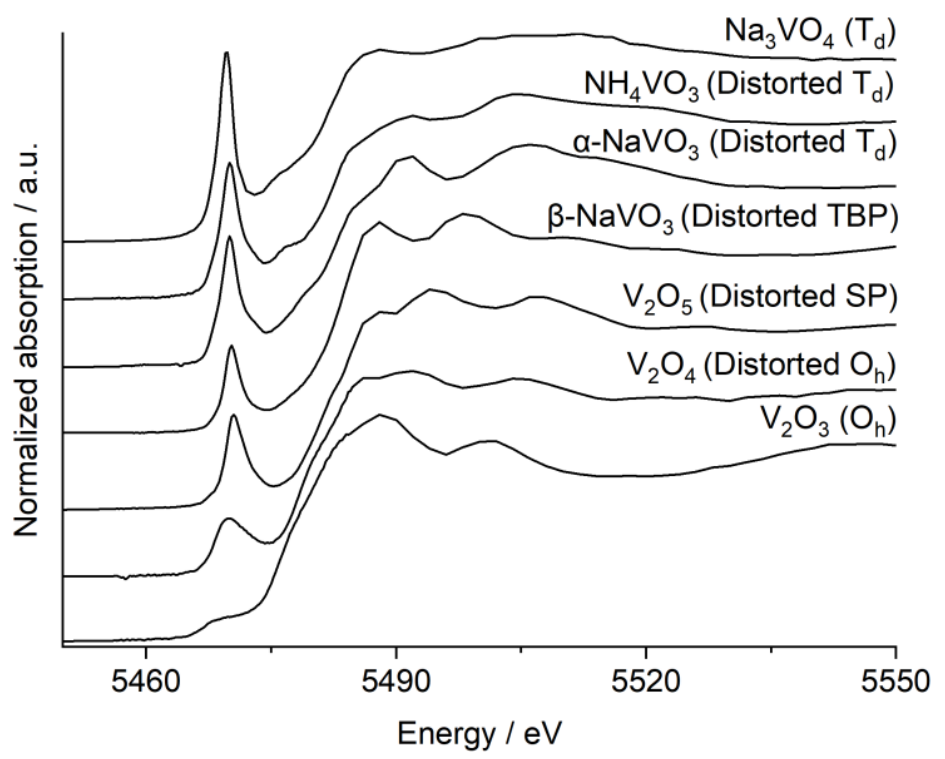

Figure S5. Dependence of pre-edge peak height and energy position on the $\mathrm{V}$ coordination geometry.

$\mathrm{T}_{d}$, TBP, SP, and $\mathrm{O}_{h}$ stand for tetrahedral, trigonal bipyramidal, square pyramidal, and octahedral respectively.

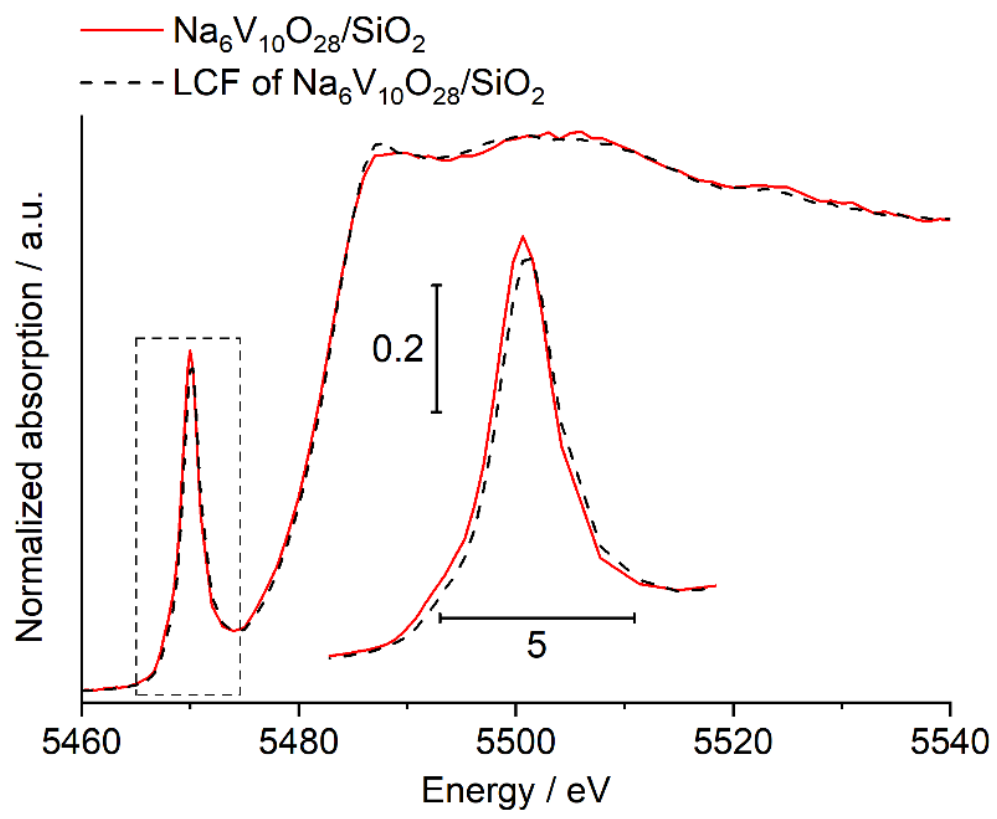

Figure S6. $V$ K-edge XANES linear combination fitting (LCF) of $\mathrm{Na}_{6} \mathrm{~V}_{10} \mathrm{O}_{28} / \mathrm{SiO}_{2}$ using $\beta-\mathrm{NaVO}_{3}$ and $\mathrm{Na}_{1+x} \mathrm{~V}_{3} \mathrm{O}_{8} / \mathrm{SiO}{ }_{2}$ as reference materials.

The fitted amounts of $\beta-\mathrm{NaVO}_{3}$ and $\mathrm{Na}_{1+\mathrm{x}} \mathrm{V}_{3} \mathrm{O}_{8} / \mathrm{SiO}_{2}$ are 34 and $66 \%$, respectively. 

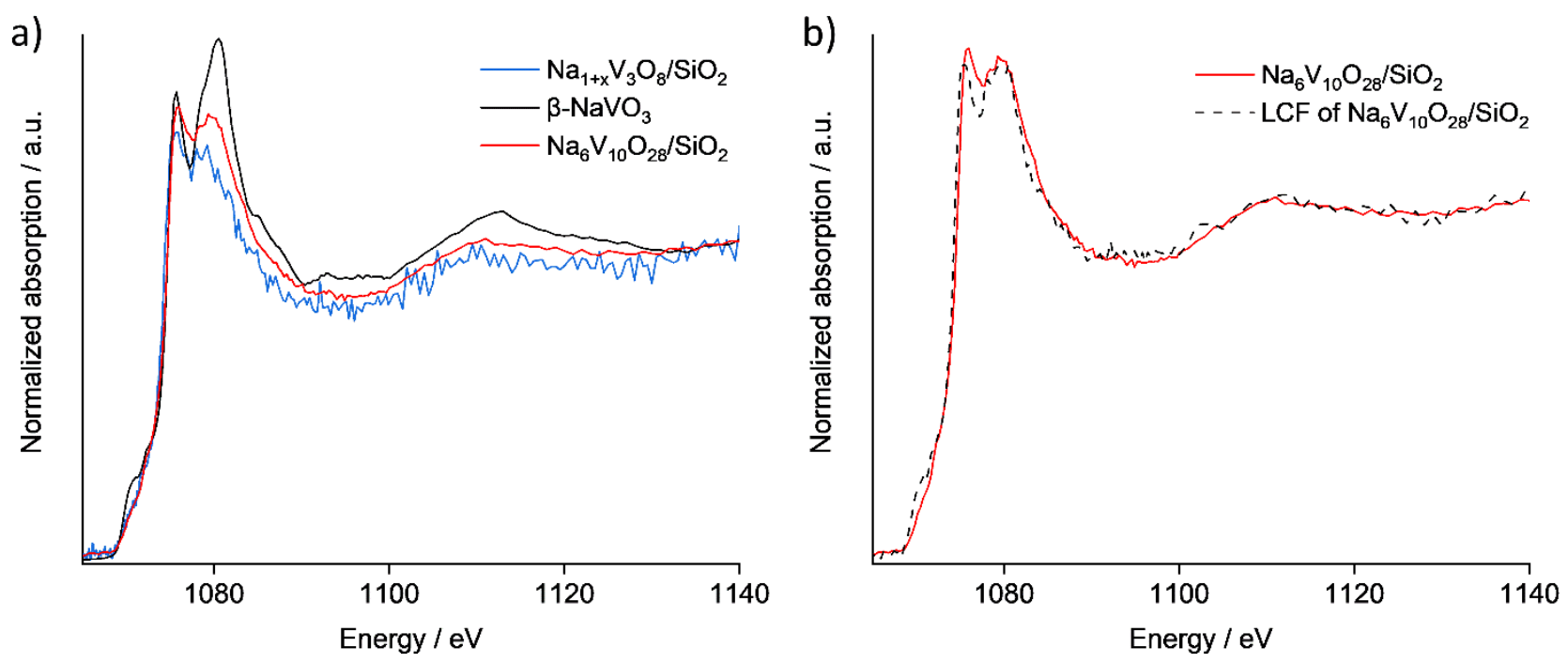

Figure S7. $\mathrm{Na} \mathrm{K}$-edge XANES linear combination fitting (LCF) of $\mathrm{Na}_{6} \mathrm{~V}_{10} \mathrm{O}_{28} / \mathrm{SiO}_{2}$ using $\beta-\mathrm{NaVO}_{3}$ and $\mathrm{Na}_{1+x} \mathrm{~V}_{3} \mathrm{O}_{8} / \mathrm{SiO} \mathrm{O}_{2}$ as reference materials.

The fitted amounts of $\beta-\mathrm{NaVO}_{3}$ and $\mathrm{Na}_{1+\mathrm{x}} \mathrm{V}_{3} \mathrm{O}_{8} / \mathrm{SiO}_{2}$ are 44 and $56 \%$, respectively.

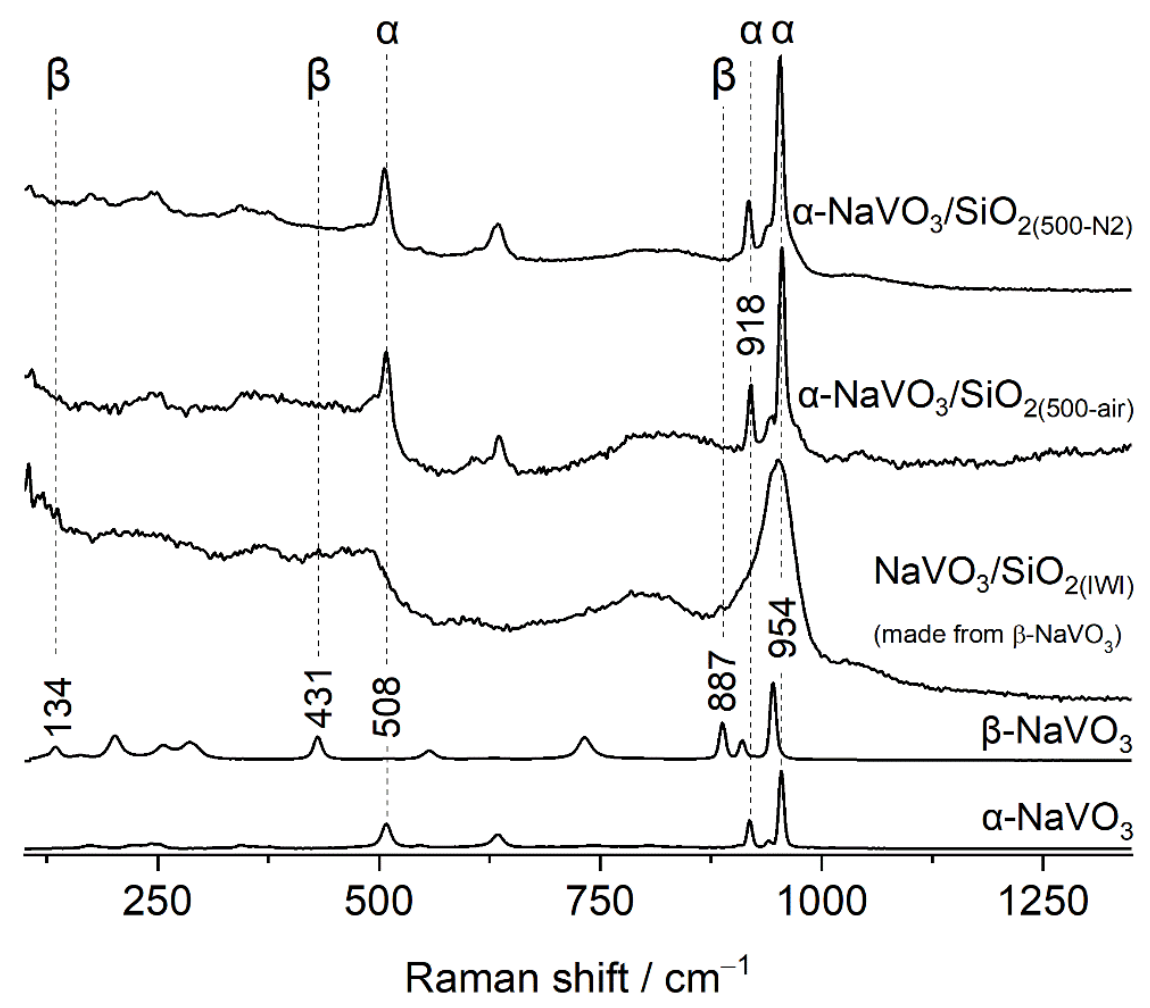

Figure S8. Raman spectra of $\alpha-\mathrm{NaVO}_{3} / \mathrm{SiO}_{2}$ before and after calcination (followed by $\mathrm{N}_{2}$ or air treatment). Surface structures do not change after air or $\mathrm{N}_{2}$ treatment. 


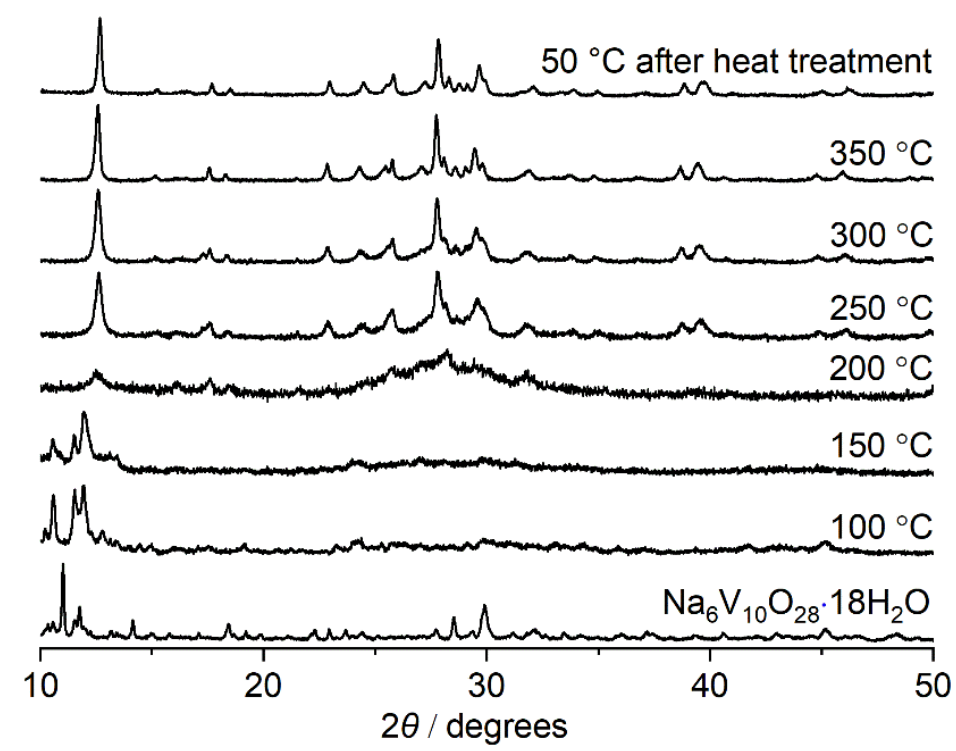

Figure S9. Calcination of $\mathrm{Na}_{6} \mathrm{~V}_{10} \mathrm{O}_{28} \cdot 18 \mathrm{H}_{2} \mathrm{O}\left(30 \mathrm{ml} \mathrm{min}^{-1}\right.$, air) followed by in situ XRD.

Thermal decomposition of $\mathrm{Na}_{6} \mathrm{~V}_{10} \mathrm{O}_{28} \cdot 18 \mathrm{H}_{2} \mathrm{O}$ yields $\mathrm{Na}_{1.164} \mathrm{~V}_{3} \mathrm{O}_{8}$ and $\alpha-\mathrm{NaVO}_{3}$ (see Figure $\mathrm{S} 10$ for diffractograms of reference materials).

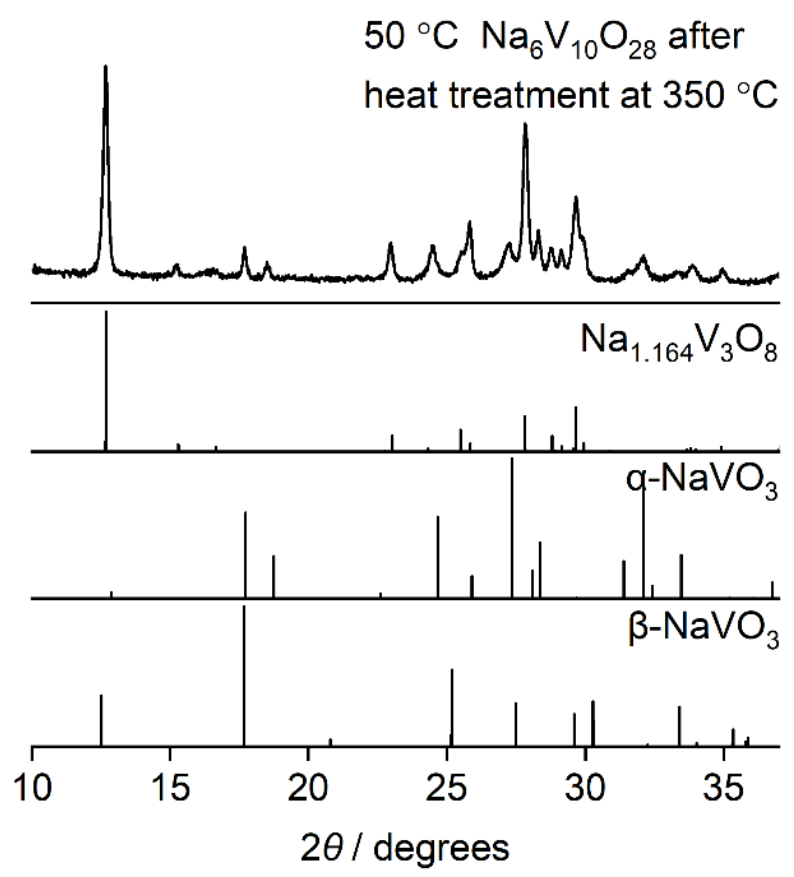

Figure S10. Diffractograms of reference materials and $\mathrm{Na}_{6} \mathrm{~V}_{10} \mathrm{O}_{28} \cdot 18 \mathrm{H}_{2} \mathrm{O}$ heated up to $350{ }^{\circ} \mathrm{C}\left(30 \mathrm{ml} \mathrm{min}^{-1}\right.$, air). 


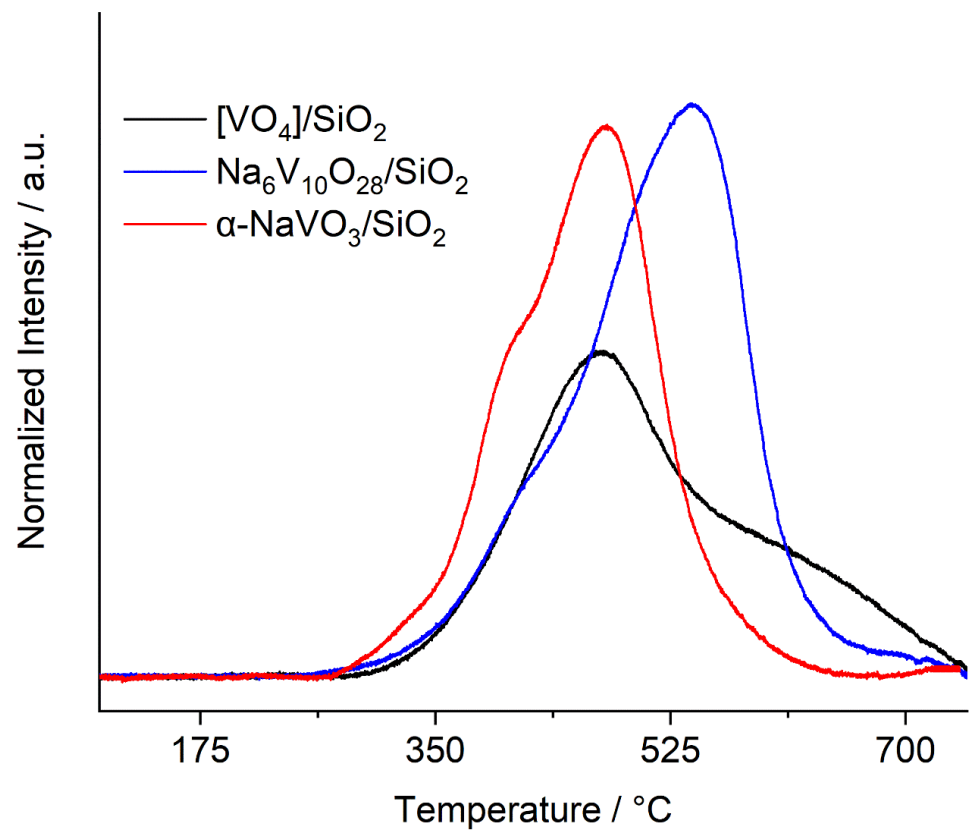

Figure S11. $\mathrm{H}_{2}$ temperature programmed reduction (TPR) of studied catalysts.

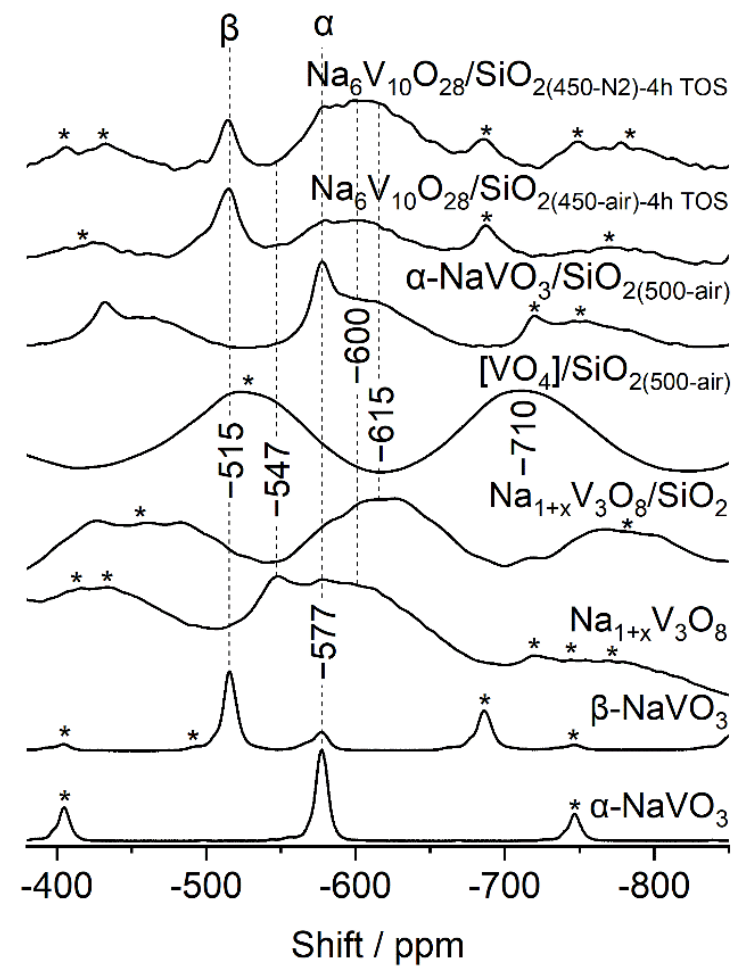

Figure $\mathrm{S} 12 .{ }^{51} \mathrm{~V}$ MAS NMR spectra of $\mathrm{Na}_{6} \mathrm{~V}_{10} \mathrm{O}_{28} / \mathrm{SiO}_{2}$ after $4 \mathrm{~h} \mathrm{TOS}, \mathrm{N}_{2}$ or air pre-treatment $\left(450{ }^{\circ} \mathrm{C}, 1 \mathrm{~h}\right)$ along with references.

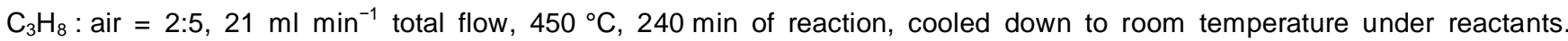
$15-18 \mathrm{kHz}$ spinning rates were used, sidebands are marked by asterisks. 


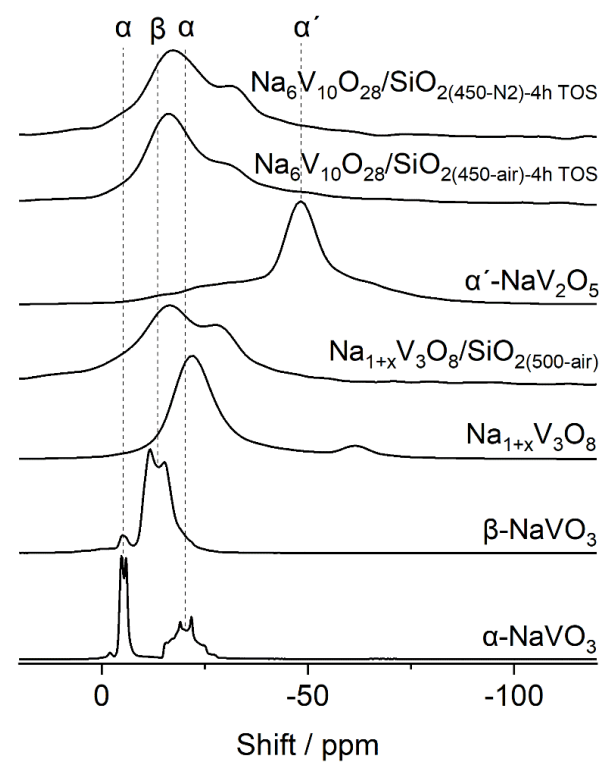

Figure S13. ${ }^{23} \mathrm{Na}$ MAS NMR of spent $\mathrm{Na}_{6} \mathrm{~V}_{10} \mathrm{O}_{28} / \mathrm{SiO}_{2}$ pre-treated under $\mathrm{N}_{2}$ or air at $450{ }^{\circ} \mathrm{C}$ for $1 \mathrm{~h}$.

$\mathrm{C}_{3} \mathrm{H}_{8}$ : air $=2: 5,21 \mathrm{ml} \mathrm{min}^{-1}$ total flow, $450^{\circ} \mathrm{C}, 240 \mathrm{~min}$ of reaction, cooled down to room temperature under reactants. $15-18 \mathrm{kHz}$ spinning rates were used.

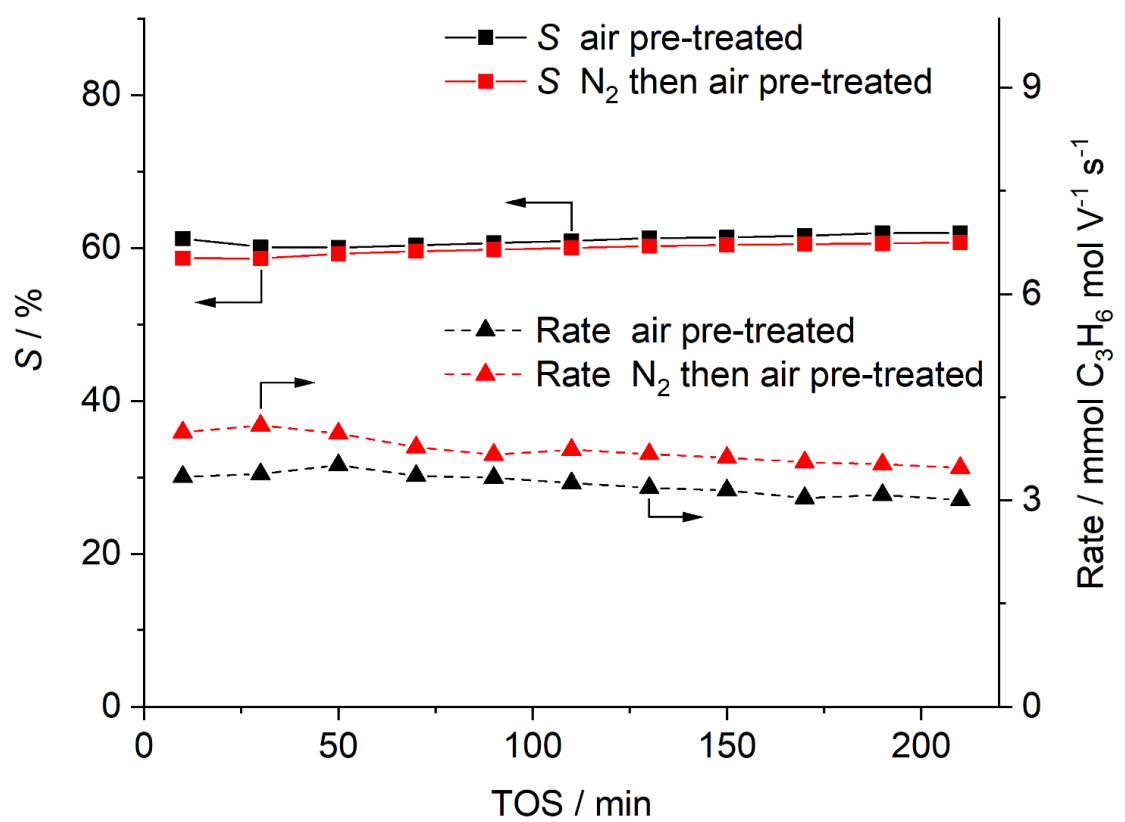

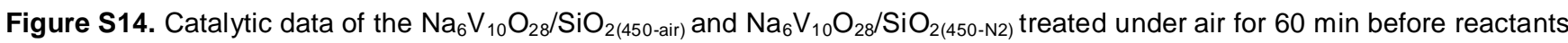
introduction.

OPD $\left(\mathrm{C}_{3} \mathrm{H}_{8}\right.$ : air $\left.=2: 5\right)$ at $450{ }^{\circ} \mathrm{C}$ using WHSV of $6.8 \mathrm{~h}^{-1}$. 


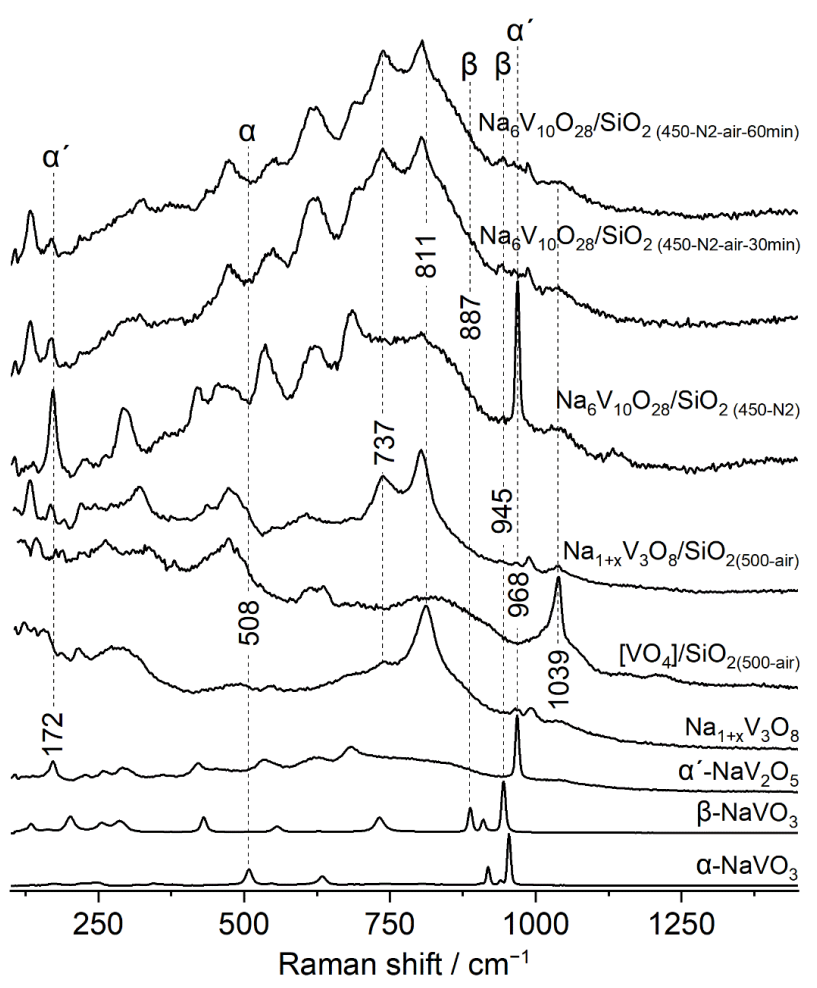

Figure S15. Raman spectra of $\mathrm{Na}_{6} \mathrm{~V}_{10} \mathrm{O}_{28} / \mathrm{SiO}_{2(450-\mathrm{N} 2)}$ after $30 \mathrm{~min}$ and $60 \mathrm{~min}$ exposure to air at $450{ }^{\circ} \mathrm{C}$. All spectra are collected at room temperature under $\mathrm{N}_{2}$ atmosphere after high temperature treatment using $\mathrm{N}_{2}$ or air.

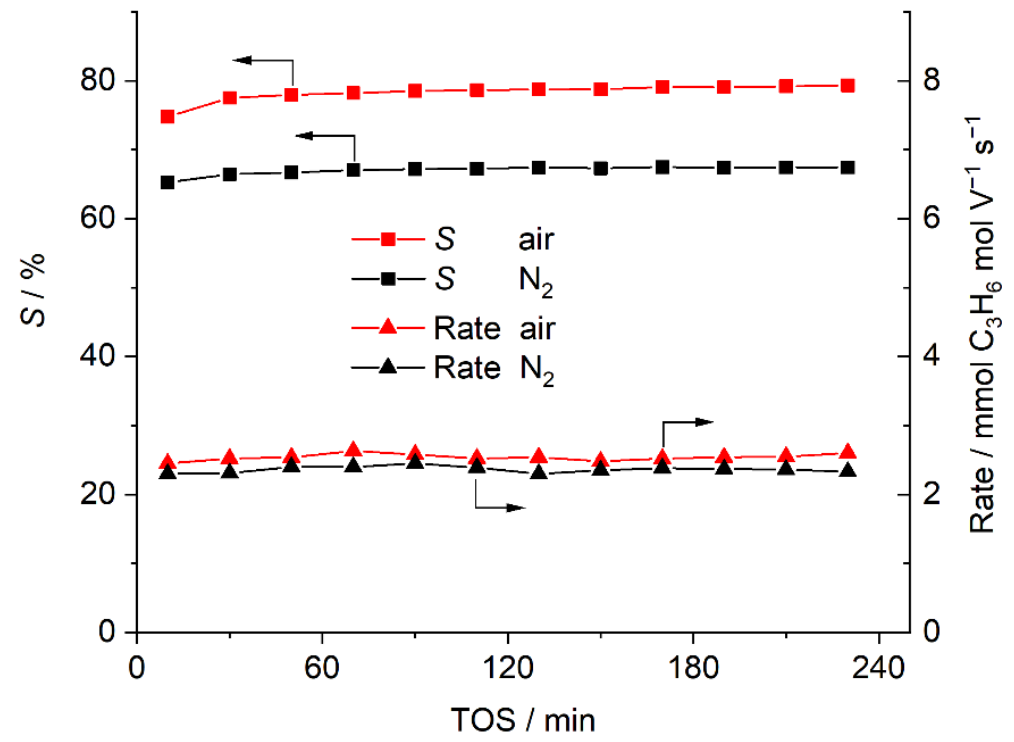

Figure S16. Propene selectivity vs TOS for $\left[\mathrm{VO}_{4}\right] / \mathrm{SiO}_{2}$ catalyst treated under air or $\mathrm{N}_{2}$ for $1 \mathrm{~h}$ at $450{ }^{\circ} \mathrm{C}$.

$\mathrm{C}_{3} \mathrm{H}_{8}:$ air $=2: 5,21 \mathrm{ml} \mathrm{min}^{-1}$ total flow, $450{ }^{\circ} \mathrm{C}$. 


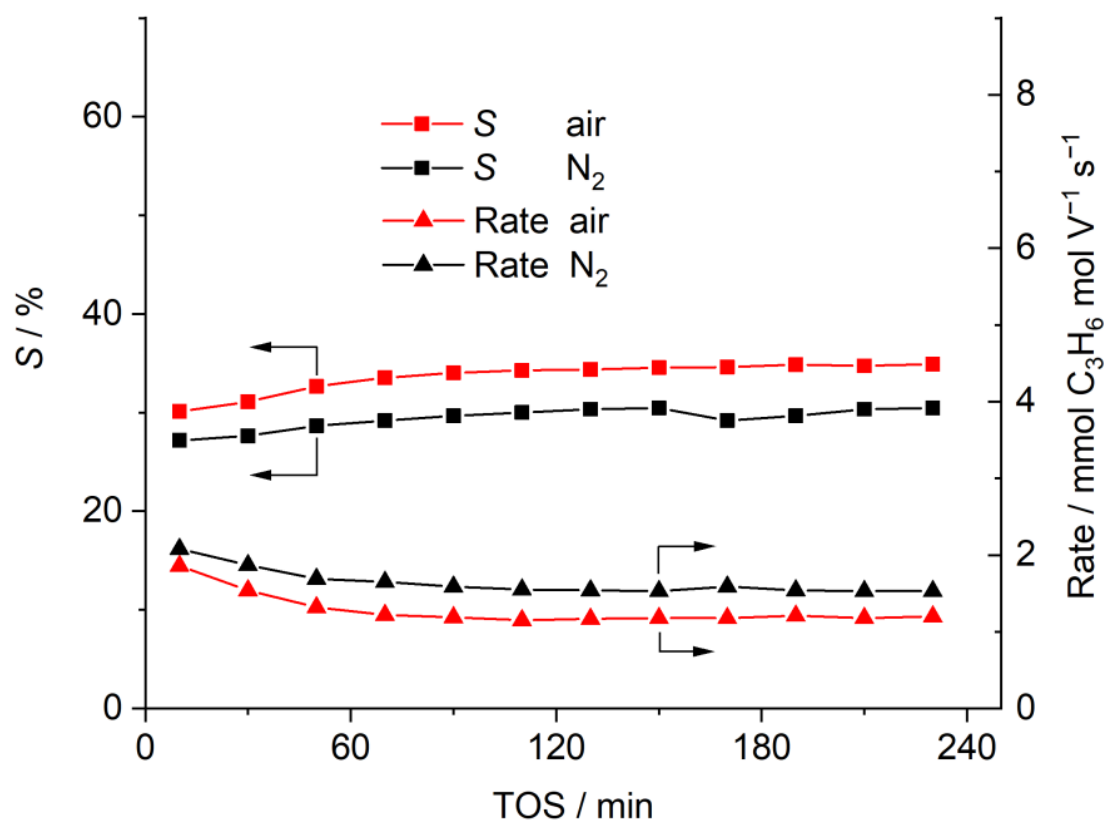

Figure S17. Propene selectivity vs TOS for $\alpha-\mathrm{NaVO}_{3} / \mathrm{SiO}_{2}$ (prepared from $\beta-\mathrm{NaVO}_{3}$ precursor, calcined at $600{ }^{\circ} \mathrm{C}, \sim 1 \mathrm{~V} \mathrm{~nm}{ }^{-1}$ ) catalyst, treated under air or $\mathrm{N}_{2}$ for $1 \mathrm{~h}$ at $450^{\circ} \mathrm{C}$.

$\mathrm{C}_{3} \mathrm{H}_{8}:$ air $=2: 5,21 \mathrm{ml} \mathrm{min}^{-1}$ total flow, $450{ }^{\circ} \mathrm{C}$.

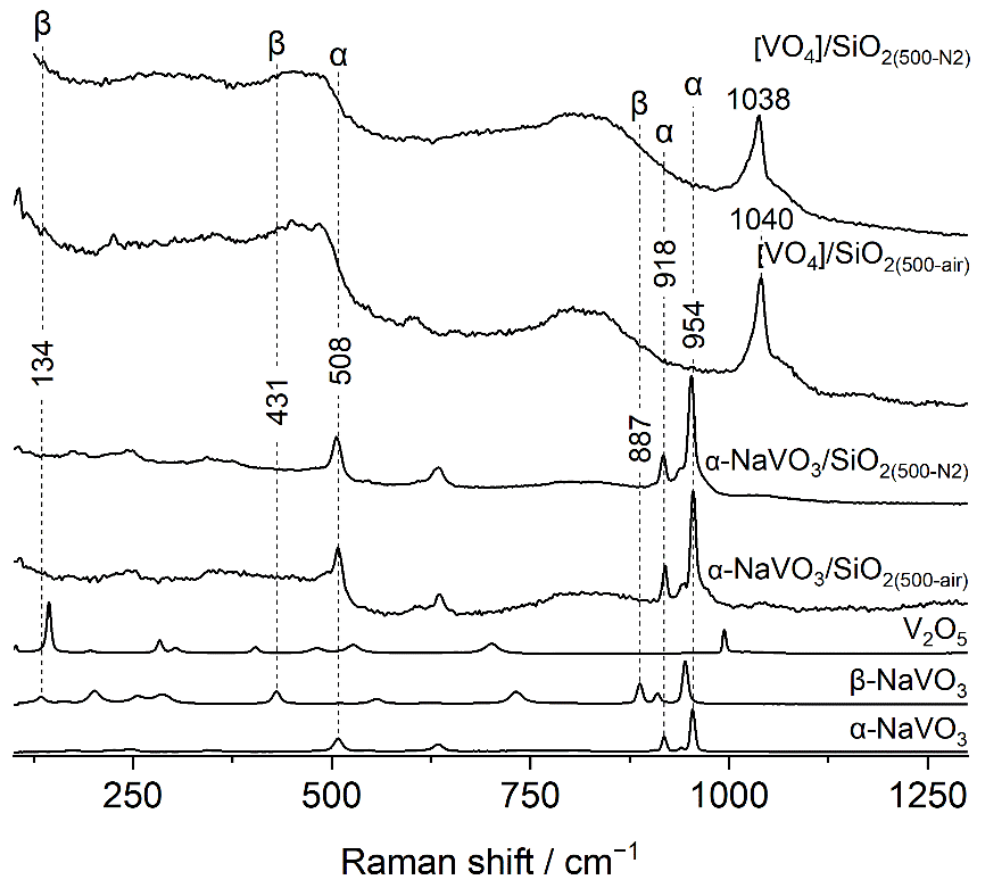

Figure S18. Raman spectra of $\mathrm{N}_{2}$ and air treated $\left[\mathrm{VO}_{4}\right] / \mathrm{SiO}_{2}$ and $\alpha-\mathrm{NaVO}_{3} / \mathrm{SiO}_{2}$.

Catalysts were treated under air or $\mathrm{N}_{2}\left(30 \mathrm{ml} \mathrm{min}^{-1}\right)$ for $1 \mathrm{~h}$ at $450{ }^{\circ} \mathrm{C}$. 


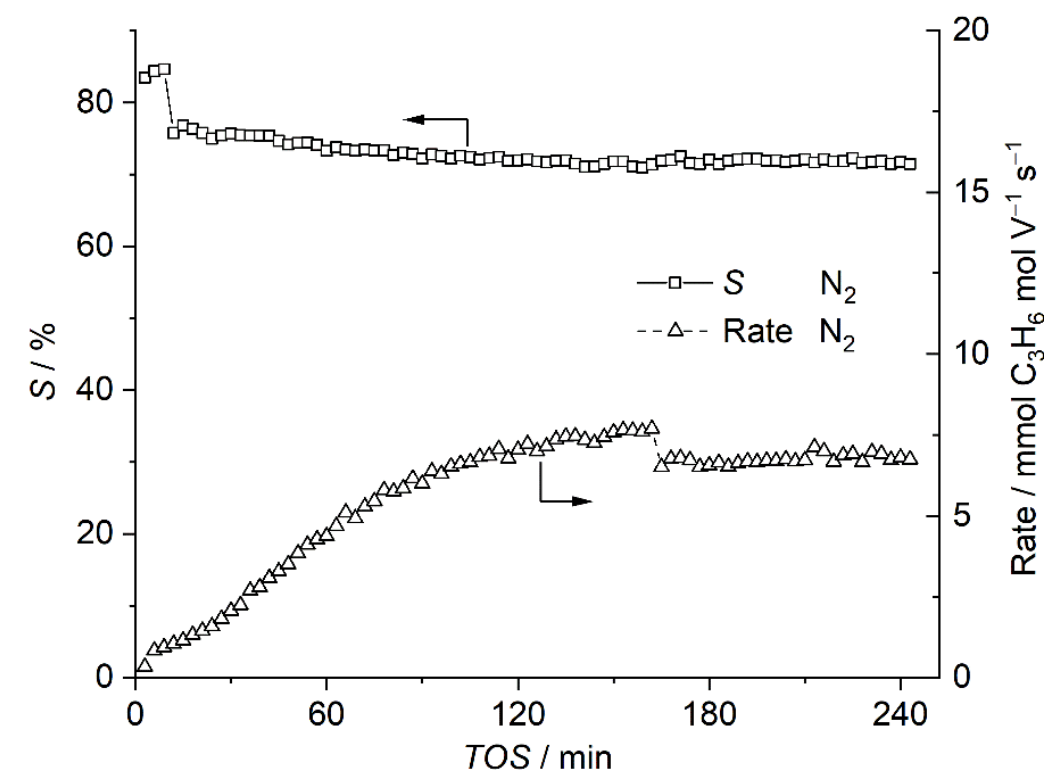

Figure S19. Composition of the effluent during the operando XANES ODP experiment with $\mathrm{Na}_{6} \mathrm{~V}_{10} \mathrm{O}_{28} / \mathrm{SiO}_{2(450-\mathrm{N} 2) \text {. }}$

ODP at $450{ }^{\circ} \mathrm{C}, \mathrm{C}_{3} \mathrm{H}_{8}:$ air $=2: 5, \mathrm{WHSV}=9.7 \mathrm{~h}^{-1}$.
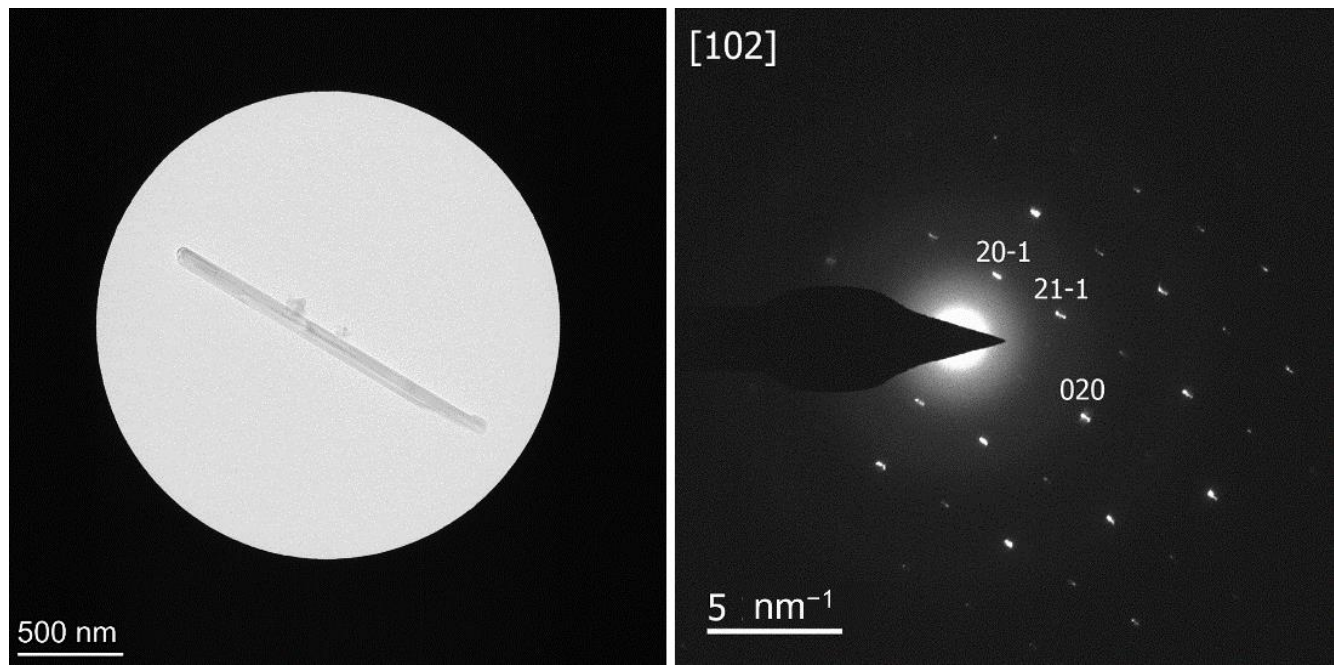

Figure S20. Selected area electron diffraction (SAED) of a nanorod in $\mathrm{Na}_{6} \mathrm{~V}_{10} \mathrm{O}_{28} / \mathrm{SiO}_{2(450-\mathrm{N} 2)}$ after 12 min TOS under ODP conditions $\left(\mathrm{WHSV}=6.8 \mathrm{~h}^{-1}\right)$.

Diffraction pattern can be indexed to that of $\mathrm{Na}_{1.164} \mathrm{~V}_{3} \mathrm{O}_{8}$ oriented along [102] zone axis. ${ }^{[14]}$ 


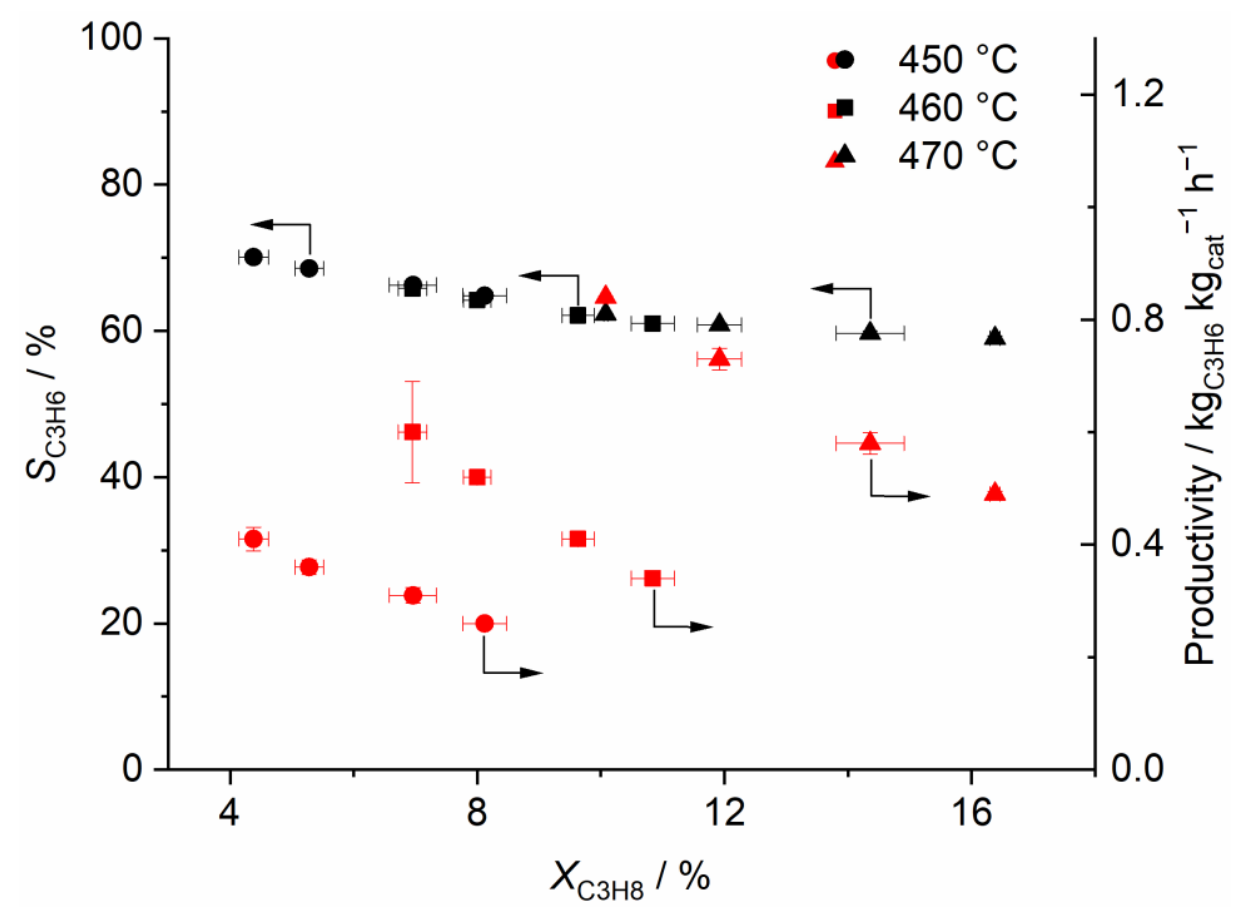

Figure S21. Propylene selectivity and productivity vs. propane conversion at different temperatures for air treated (1 $\mathrm{h}$ at designated temperatures) $\mathrm{Na}_{6} \mathrm{~V}_{10} \mathrm{O}_{28} / \mathrm{SiO}_{2}$ catalyst.

WHSV was varied between $5.1-13.6 \mathrm{~h}^{-1}$ by varying total flow (15.8-42 $\mathrm{ml} \mathrm{min}^{-1}$ ) of the feed. Partial pressures of $\mathrm{C}_{3} \mathrm{H}_{8}$ and $\mathrm{O}_{2}$ were always 0.3 and 0.15 bar (balance $\mathrm{N}_{2}$ ), respectively.

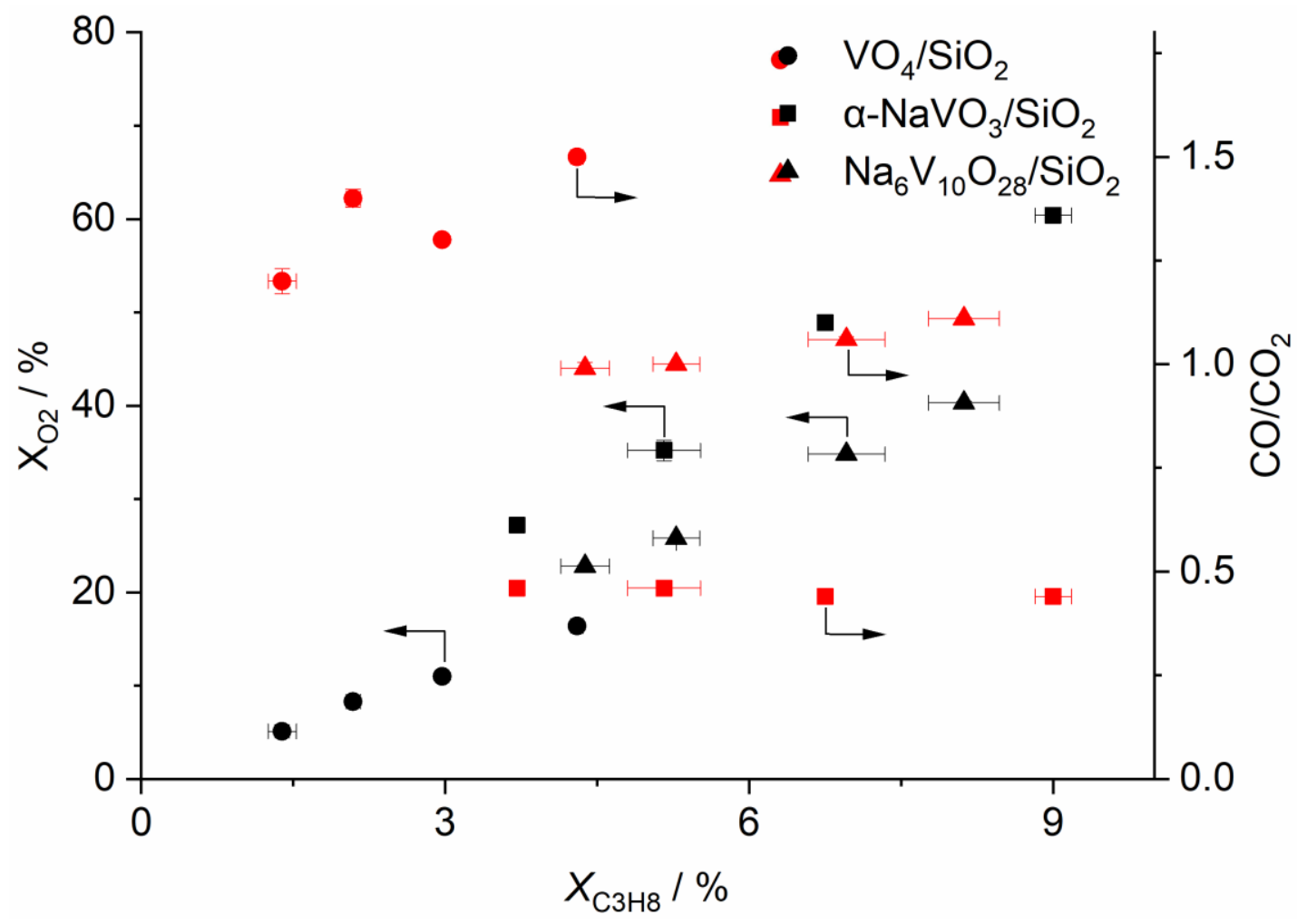

Figure S22. Oxygen conversions and $\mathrm{CO} / \mathrm{CO}_{2}$ molar ratios vs propane conversions for studied catalysts.

WHSV was varied between $5.1-13.6 \mathrm{~h}^{-1}$ by varying total flow $\left(15.8-42 \mathrm{ml} \mathrm{min}^{-1}\right)$ of the feed at $450{ }^{\circ} \mathrm{C}$. Partial pressures of $\mathrm{C}_{3} \mathrm{H}_{8}$ and $\mathrm{O}_{2}$ were always 0.3 and 0.15 bar (balance $\mathrm{N}_{2}$ ), respectively. 


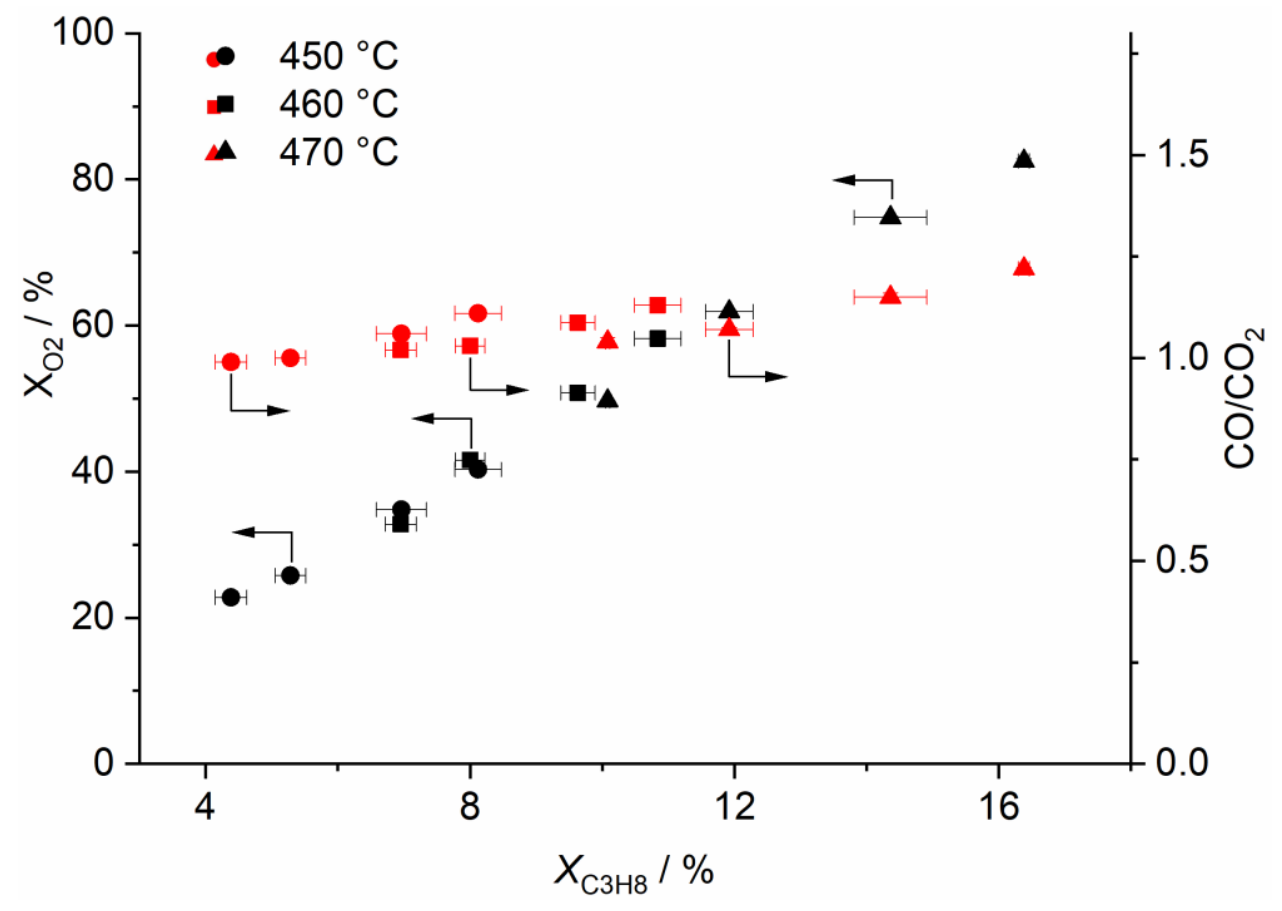

Figure S23. Oxygen conversions and $\mathrm{CO} / \mathrm{CO}_{2}$ molar ratios vs. propane conversions at different temperatures for air treated ( $1 \mathrm{~h}$ at designated temperatures) $\mathrm{Na}_{6} \mathrm{~V}_{10} \mathrm{O}_{28} / \mathrm{SiO}_{2}$ catalyst.

WHSV was varied between 5.1-13.6 $\mathrm{h}^{-1}$ by varying total flow (15.8-42 $\left.\mathrm{ml} \mathrm{min}^{-1}\right)$ of the feed at different temperatures. Partial pressures of $\mathrm{C}_{3} \mathrm{H}_{8}$ and $\mathrm{O}_{2}$ were always 0.3 and 0.15 bar (balance $\mathrm{N}_{2}$ ), respectively.

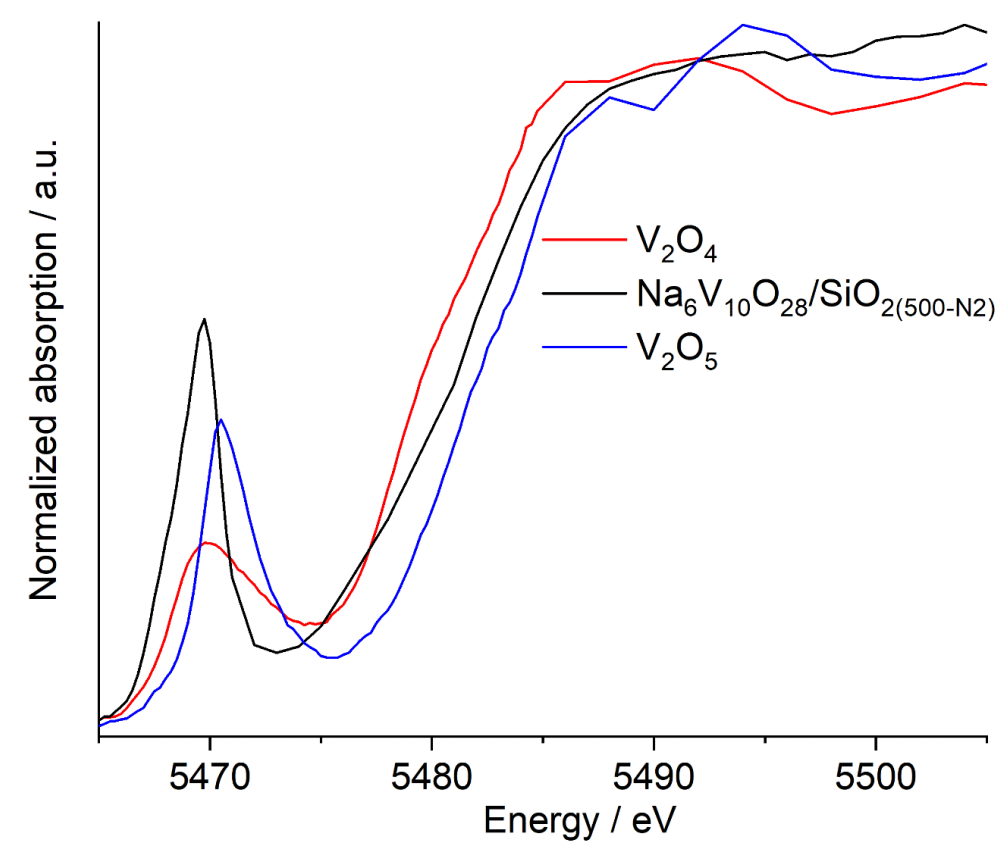

Figure S24. $\mathrm{V}$ K-edge XANES spectra of $\mathrm{Na}_{6} \mathrm{~V}_{10} \mathrm{O}_{28} / \mathrm{SiO}_{2(500-\mathrm{N} 2)}$ along with $\mathrm{V}_{2} \mathrm{O}_{4}$ and $\mathrm{V}_{2} \mathrm{O}_{5}$ references. 


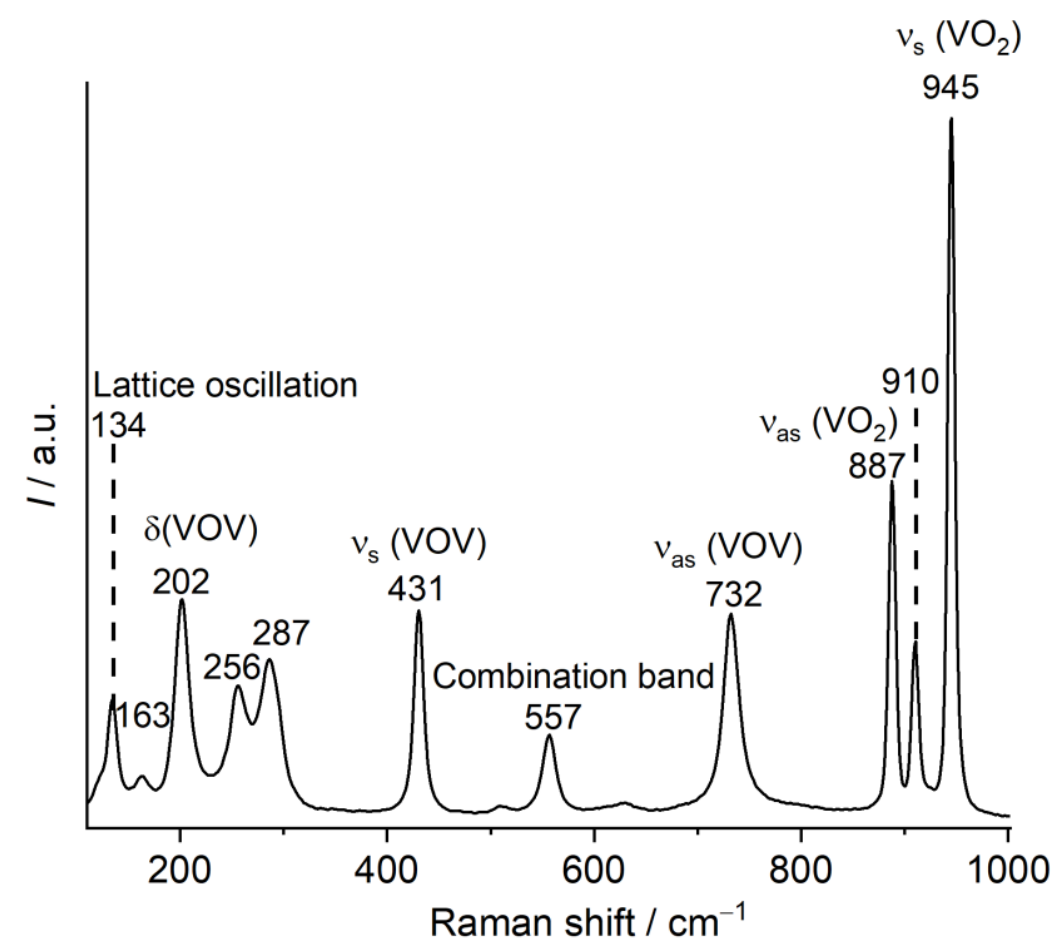

Figure S25. Full width Raman spectrum of as synthesized $\beta-\mathrm{NaVO}_{3}$.

Room temperature; assignments are according to the literature report. ${ }^{[4]} \mathrm{VOV}$ and $\mathrm{VO}_{2}$ are oscillations in chain and free modes, respectively.

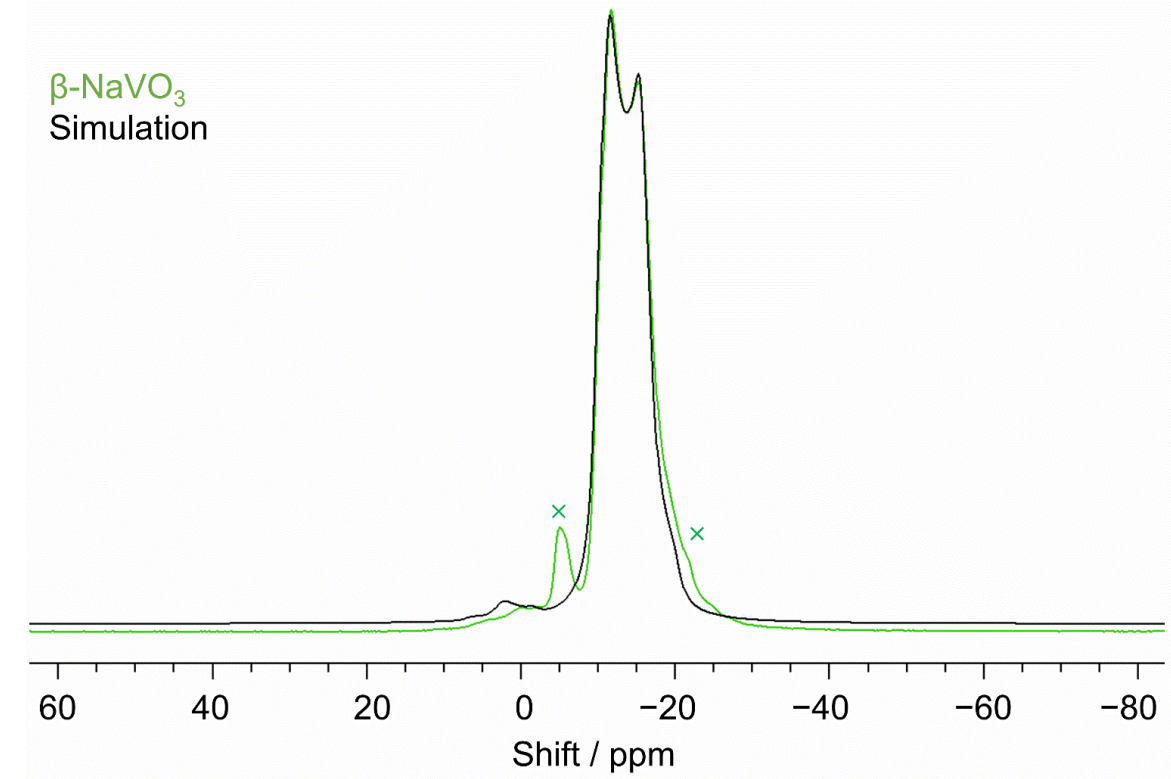

Figure S26. ${ }^{23} \mathrm{Na}$ MAS NMR of synthesized $\beta-\mathrm{NaVO}_{3}$ and simulated spectrum.

$18 \mathrm{kHz}$ spinning rate; impurities due to a $\alpha-\mathrm{NaVO}_{3}$ phase are marked by the cross sign. Quadrupolar coupling constant $\left(\mathrm{C}_{\mathrm{Q}}\right)$ and quadrupolar asymmetry parameter $\left(\mathrm{n}_{\mathrm{Q}}\right)$ are reported in Table $\mathrm{S} 1$ and $\mathrm{S} 2$. 


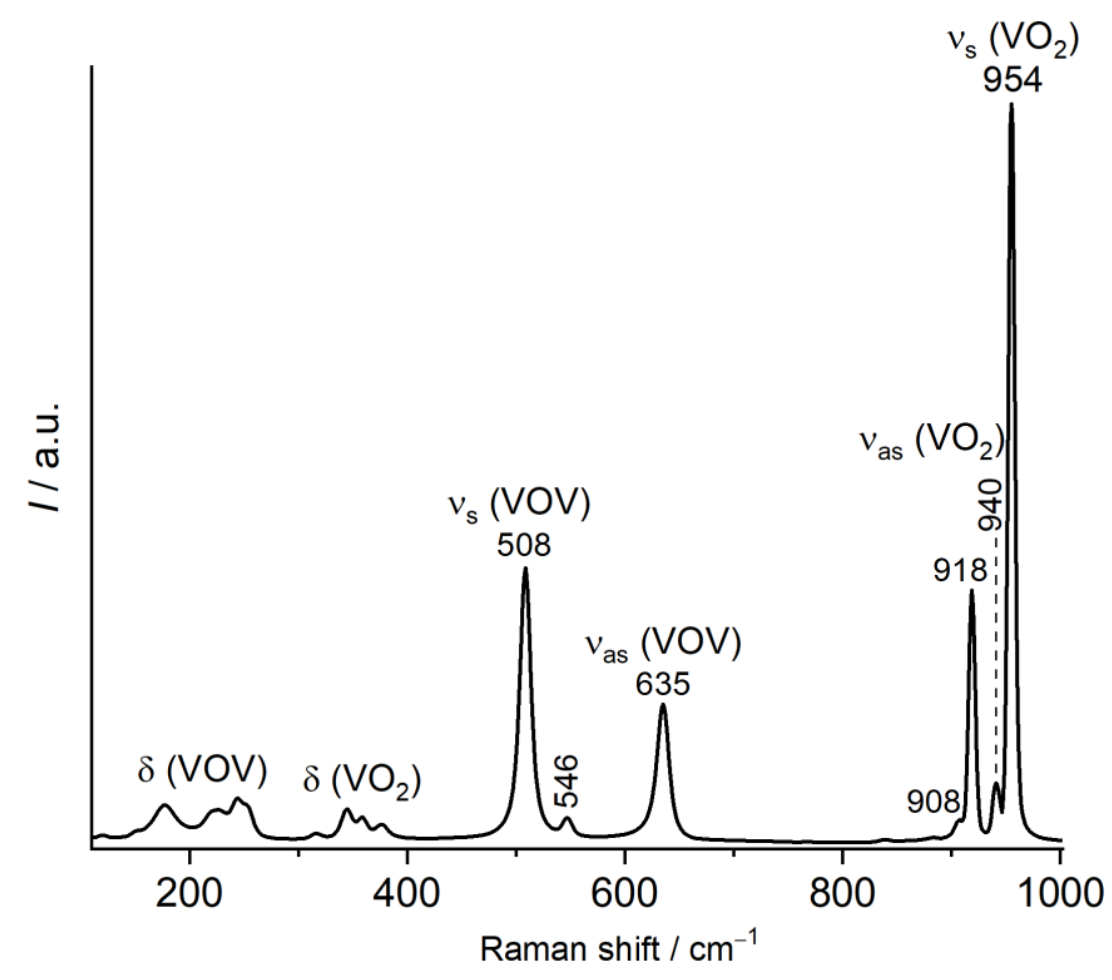

Figure S27. Full width Raman spectrum of as synthesized $\alpha-\mathrm{NaVO}_{3}$.

Room temperature; assignments are according to literature. ${ }^{[4]} \mathrm{VOV}$ and $\mathrm{VO}_{2}$ are oscillations in chain and free modes, respectively.

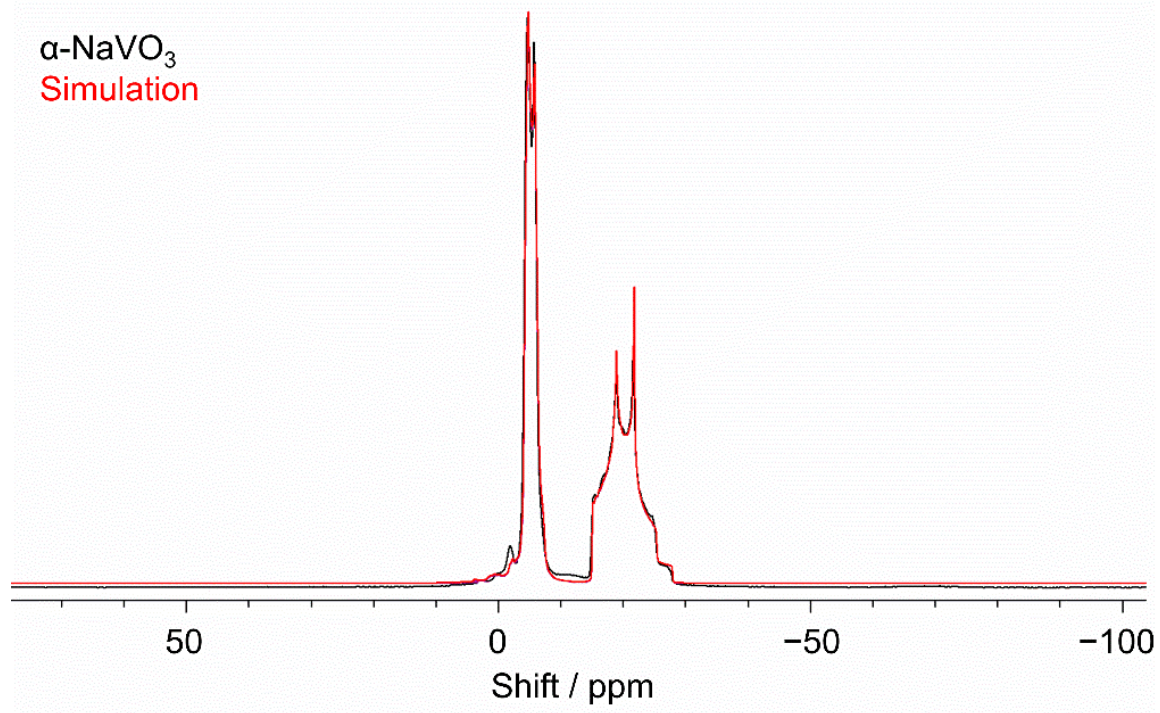

Figure S28. ${ }^{23} \mathrm{Na}$ MAS NMR of synthesized $\alpha-\mathrm{NaVO}_{3}$ and simulated spectrum.

$18 \mathrm{kHz}$ spinning rate, quadrupolar coupling constant $\left(\mathrm{C}_{\mathrm{Q}}\right)$ and quadrupolar asymmetry parameter $\left(\eta_{\mathrm{Q}}\right)$ are reported in Table S1 and S2. 


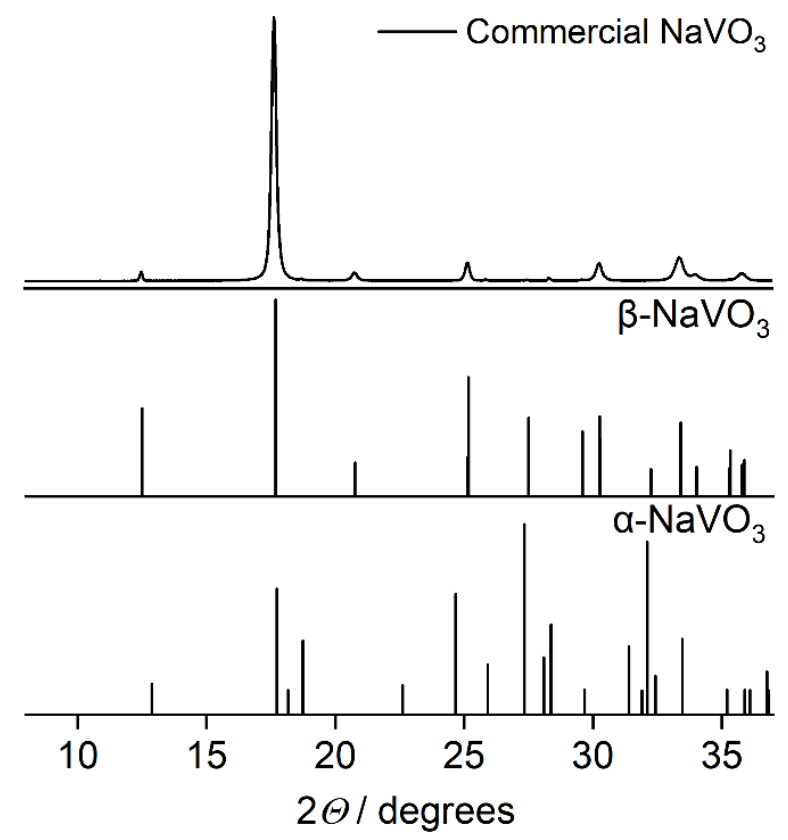

Figure S29. XRD of commercial $\mathrm{NaVO}_{3}$ (Sigma-Aldrich, Lot \#BCBR1531V).

XRD of commercial $\mathrm{NaVO}_{3}$ shows mainly diffraction peaks due to $\beta-\mathrm{NaVO}_{3}$ phase.

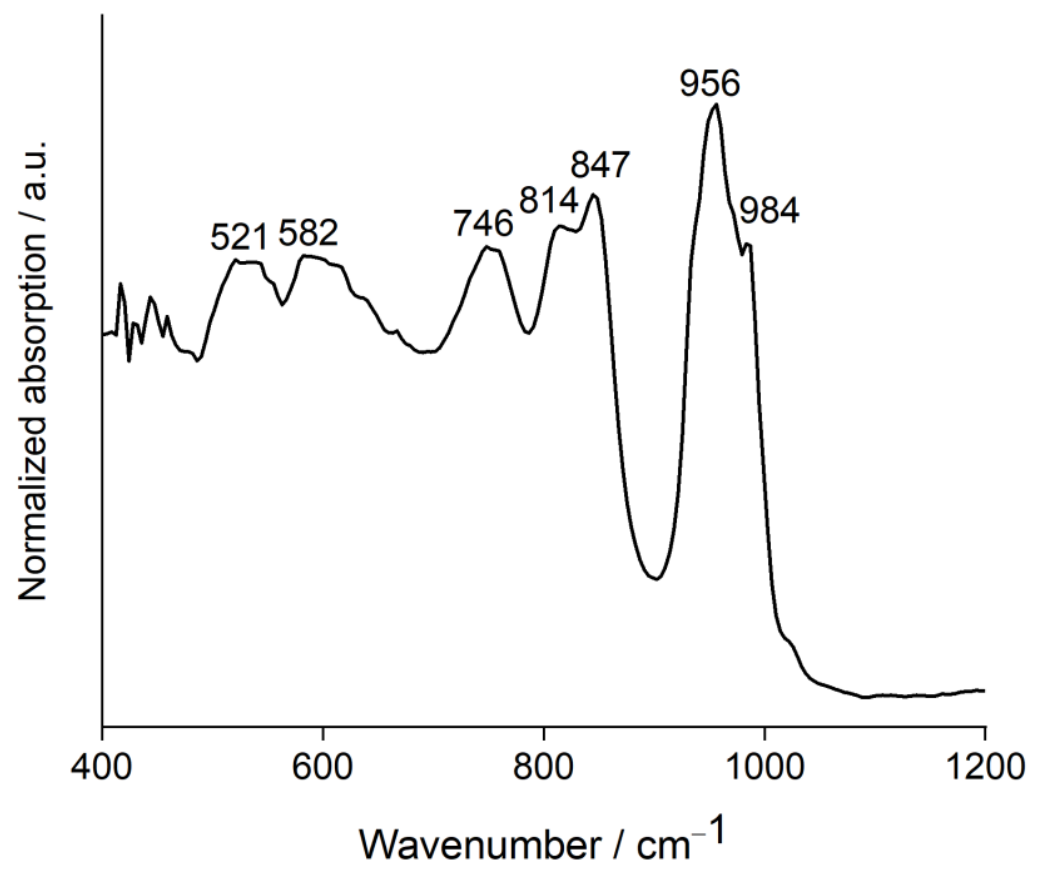

Figure S30. DRIFT spectrum of as prepared $\mathrm{Na}_{6} \mathrm{~V}_{10} \mathrm{O}_{28} \cdot 18 \mathrm{H}_{2} \mathrm{O}$.

DRIFT spectrum is consistent with the previous reports on successful synthesis of $\mathrm{Na}_{6} \mathrm{~V}_{10} \mathrm{O}_{28} \cdot 18 \mathrm{H}_{2} \mathrm{O}$. $\left.{ }^{[7 a}, 15\right]$ 


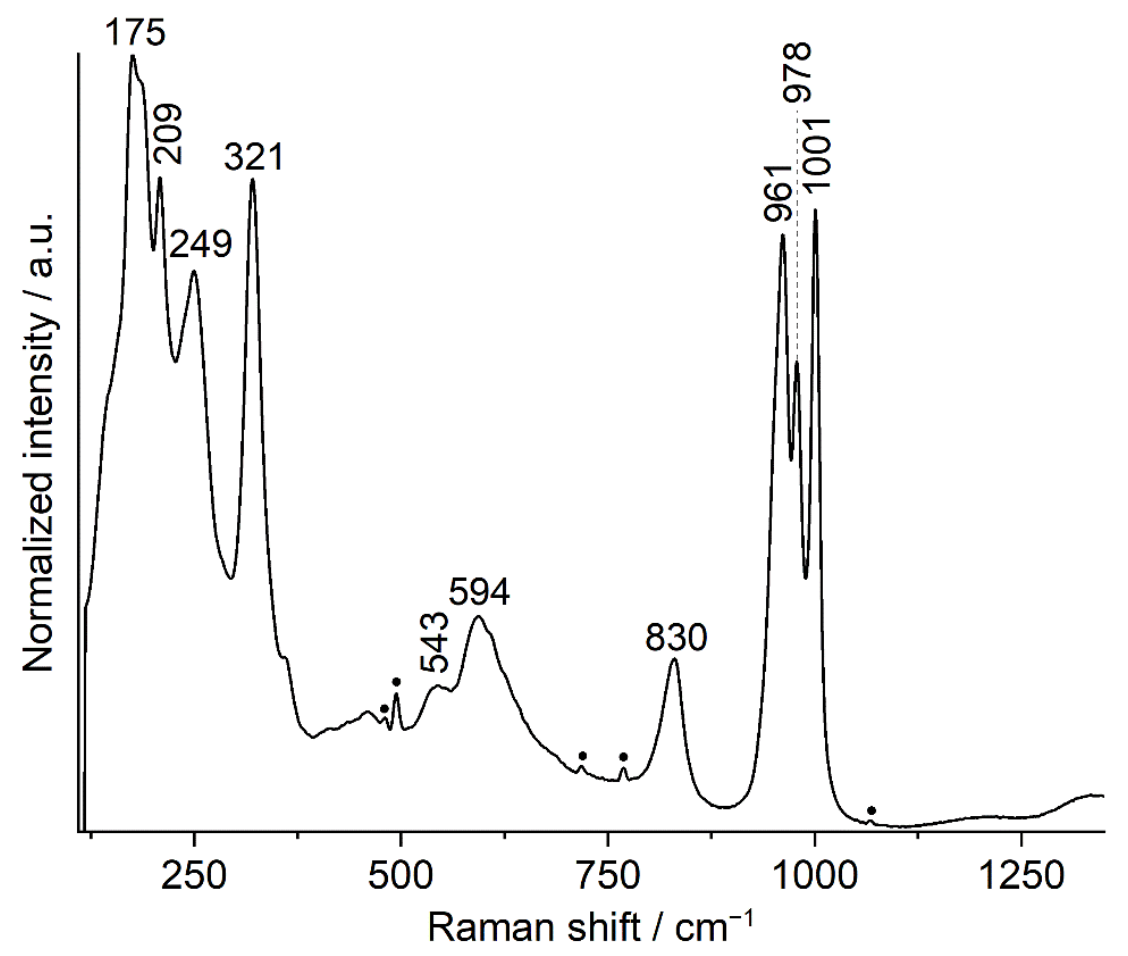

Figure S31. Raman spectrum of $\mathrm{Na}_{6} \mathrm{~V}_{10} \mathrm{O}_{28} \cdot 18 \mathrm{H}_{2} \mathrm{O}$.

Room temperature, filled circles are due to the background. Raman spectrum is consistent with the previous report. ${ }^{[7 c]}$

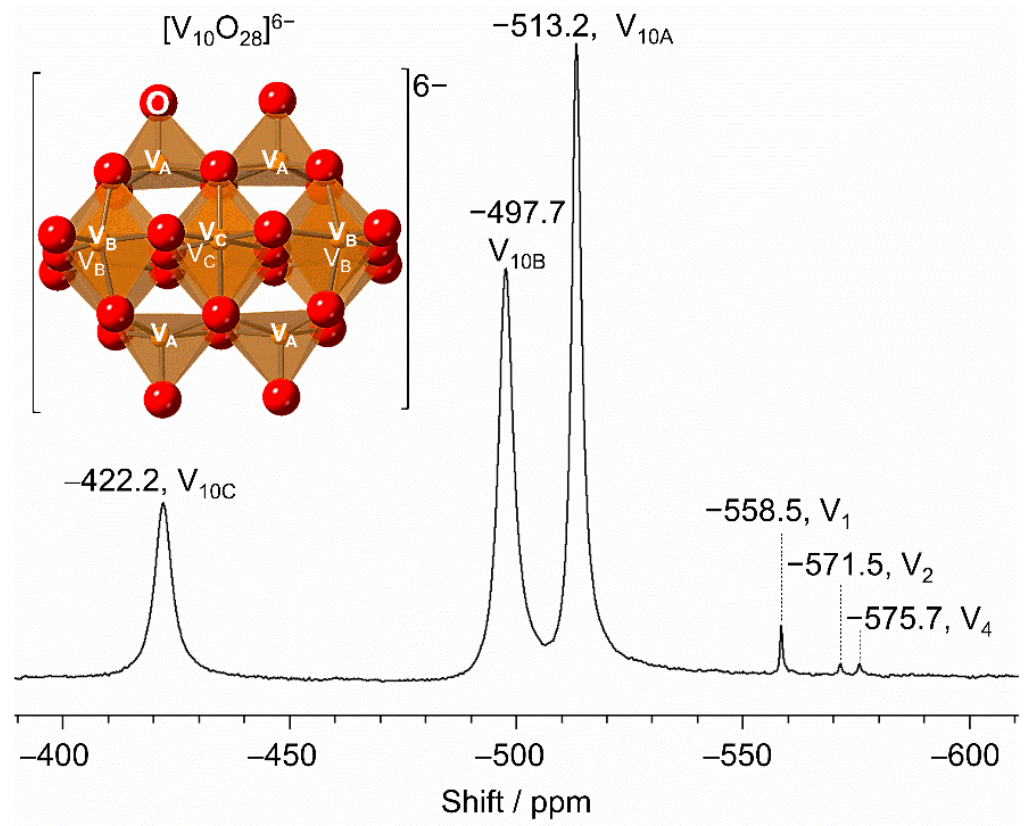

Figure S32. ${ }^{51} \mathrm{~V}$ liquid state NMR of as prepared $\mathrm{Na}_{6} \mathrm{~V}_{10} \mathrm{O}_{28} \cdot 18 \mathrm{H}_{2} \mathrm{O}$ in $\mathrm{D}_{2} \mathrm{O}$.

The combined integral of $\left[\mathrm{V}_{10} \mathrm{O}_{28}\right]^{6-}$ anion is $>97 \%$ of the overall integral. Minor species with chemical shifts at -558.5 , -571.5 , and $-575.7 \mathrm{ppm}$ are monomeric $\left[\mathrm{H}_{2} \mathrm{VO}_{4}\right]^{-}$, dimeric $\left[\mathrm{HV}_{2} \mathrm{O}_{7}\right]^{3-}$ and $\left[\mathrm{H}_{2} \mathrm{~V}_{2} \mathrm{O}_{7}\right]^{2-}$, and cyclic tetrameric $\left[\mathrm{V}_{4} \mathrm{O}_{12}\right]^{4-}$ species, respectively, which are in equilibrium with the decavanadate anion in $\mathrm{D}_{2} \mathrm{O}$ solution. ${ }^{[9]}$ 


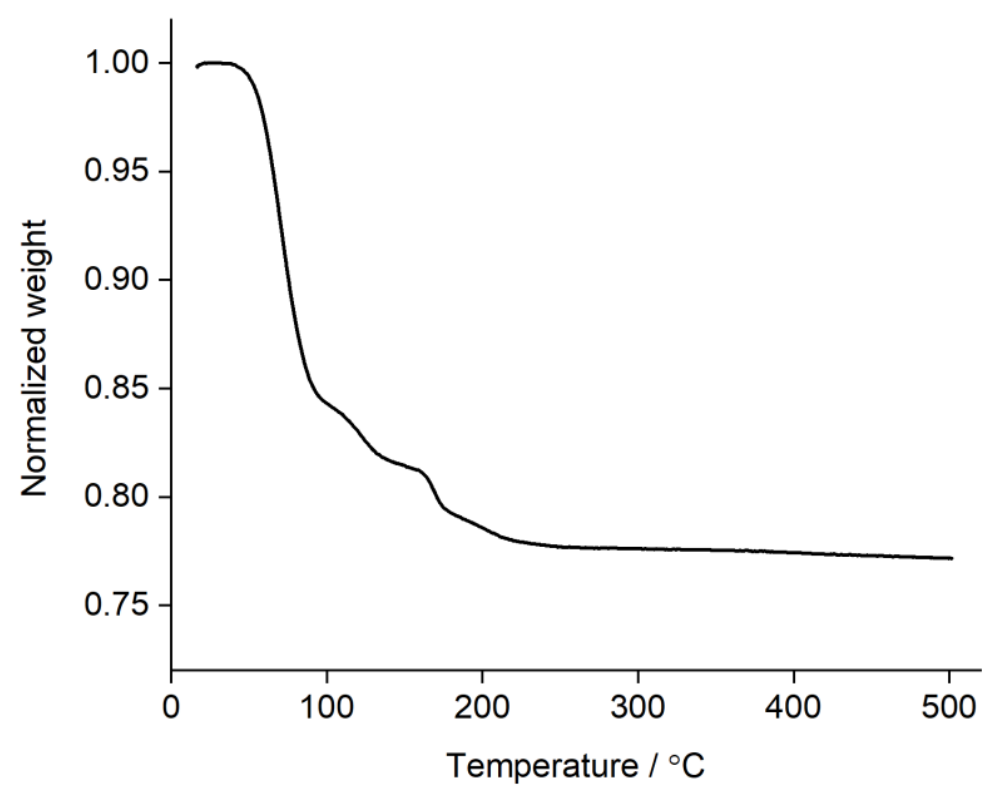

Figure S33. TGA of as prepared $\mathrm{Na}_{6} \mathrm{~V}_{10} \mathrm{O}_{28} \cdot 18 \mathrm{H}_{2} \mathrm{O}$.

Note that experimentally determined 18.3 water molecules were rounded to 18 .

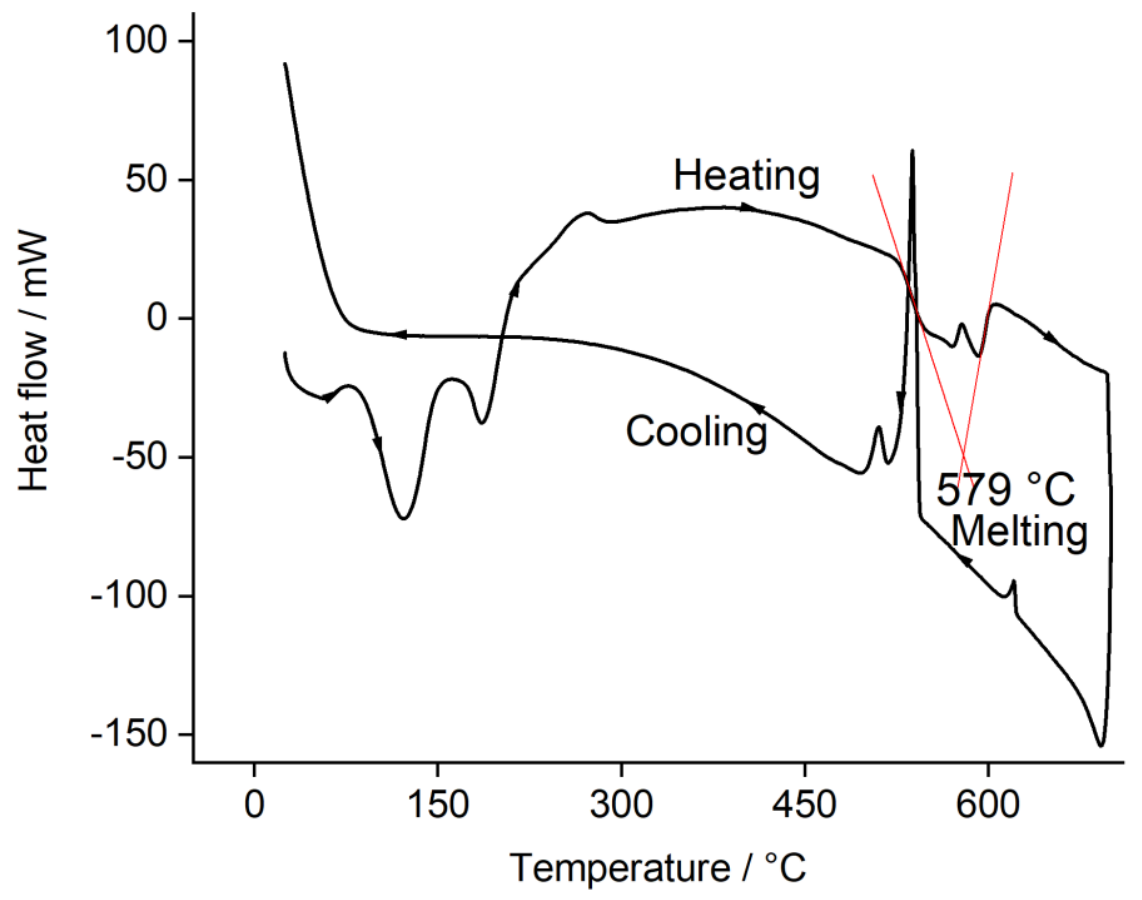

Figure S34. DSC of as prepared $\mathrm{Na}_{6} \mathrm{~V}_{10} \mathrm{O}_{28} \cdot 18 \mathrm{H}_{2} \mathrm{O}$. 


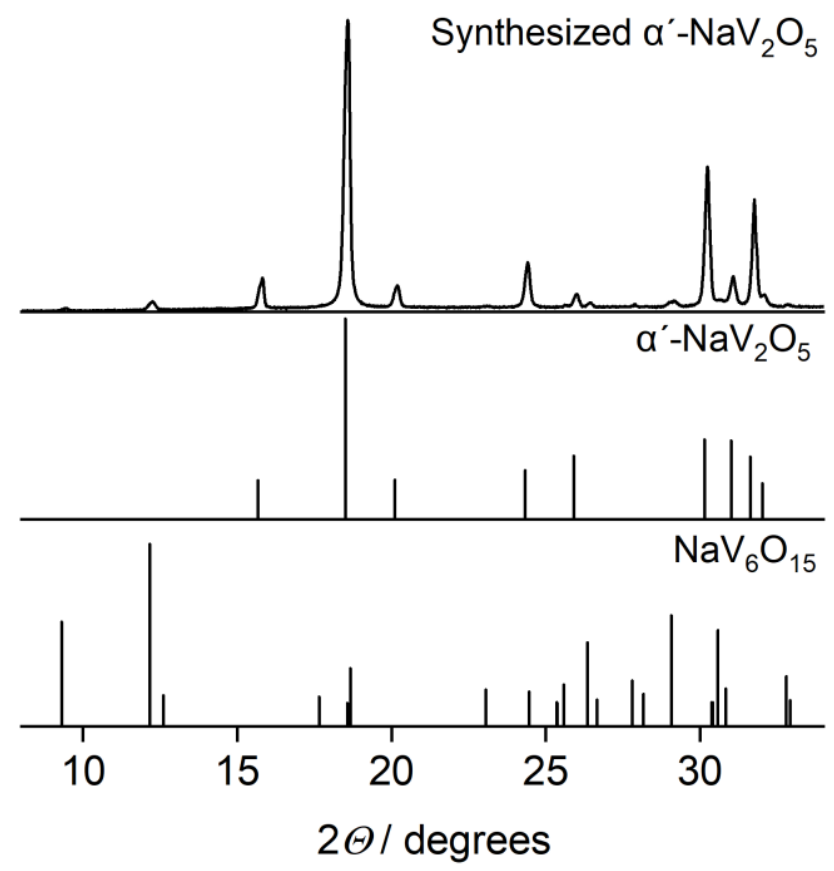

Figure S35. XRD of synthesized $\alpha^{\prime}-\mathrm{NaV}_{2} \mathrm{O}_{5}$.

Synthesized $\alpha^{\prime}-\mathrm{NaV}_{2} \mathrm{O}_{5}$ phase has some minor impurities due to $\mathrm{NaV}_{6} \mathrm{O}_{15}$ phase

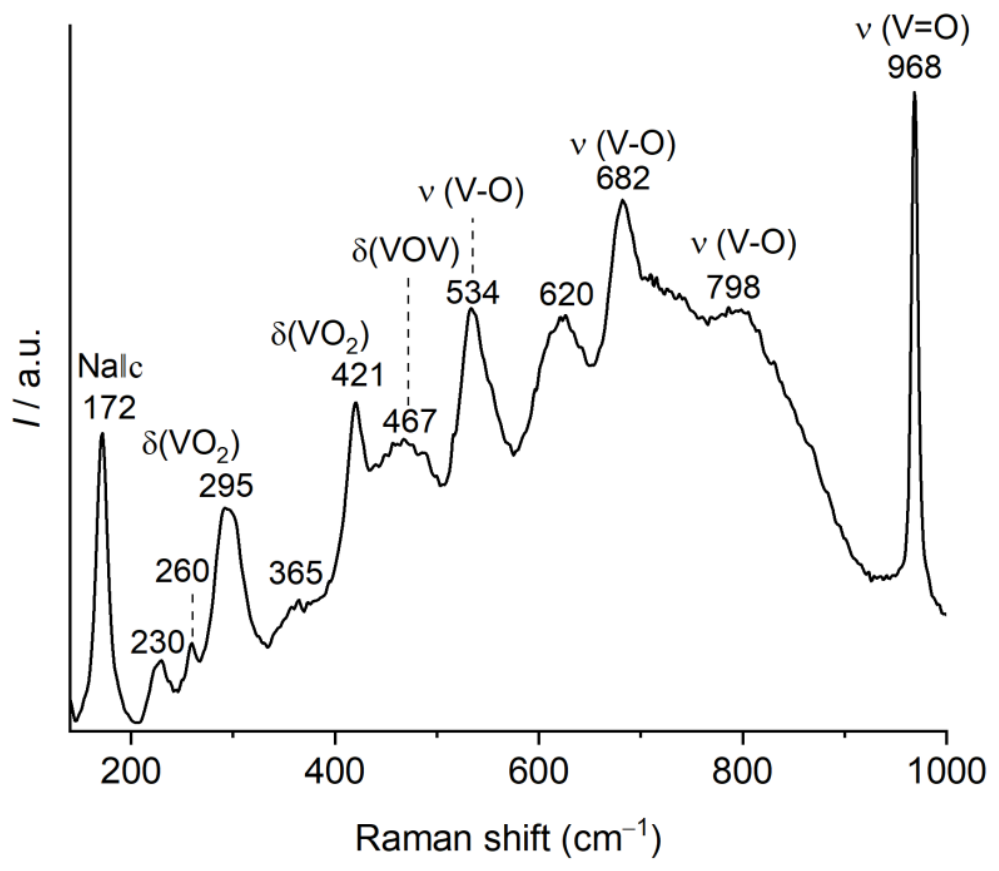

Figure S36. Raman spectrum of $\alpha^{\prime}-\mathrm{NaV}_{2} \mathrm{O}_{5}$.

Room temperature; assignments are according to literature. ${ }^{[10]}$ 


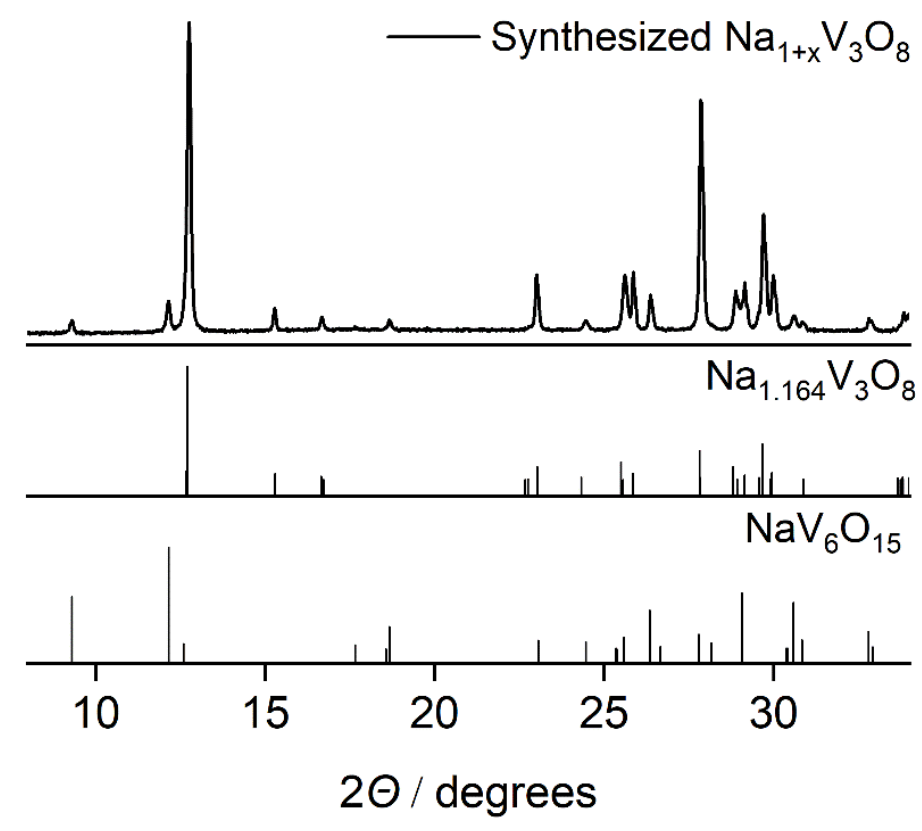

Figure S37. XRD of synthesized $\mathrm{Na}_{1+x} \mathrm{~V}_{3} \mathrm{O}_{8}$.

Synthesized $\mathrm{Na}_{1+x} \mathrm{~V}_{3} \mathrm{O}_{8}$ phase has some minor impurities due to $\mathrm{NaV}_{6} \mathrm{O}_{15}$ phase.

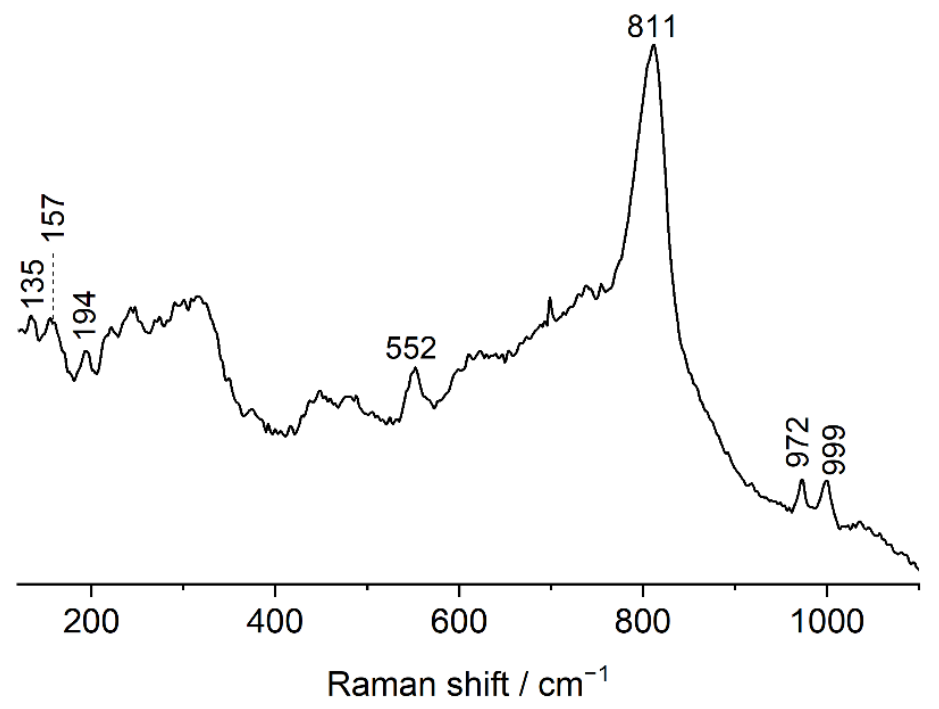

Figure S38. Full width Raman spectrum of $\mathrm{Na}_{1+x} \mathrm{~V}_{3} \mathrm{O}_{8}$.

The peaks at 999 and $972 \mathrm{~cm}^{-1}$ are due to $\mathrm{V}-\mathrm{O}$ stretching vibration of $\mathrm{VO}_{5}$ pyramids with an analogy to $\mathrm{Li}_{1+\mathrm{x}} \mathrm{V}_{3} \mathrm{O}_{8}$ iso-structure. ${ }^{[13]}$ The band at $811 \mathrm{~cm}^{-1}$ is related to the corner sharing oxygen atom between the two different $\mathrm{VO}_{5}$ and $\mathrm{VO}_{6}$ and $\mathrm{NaO}_{6}$ polyhedrons. ${ }^{[13]}$ 


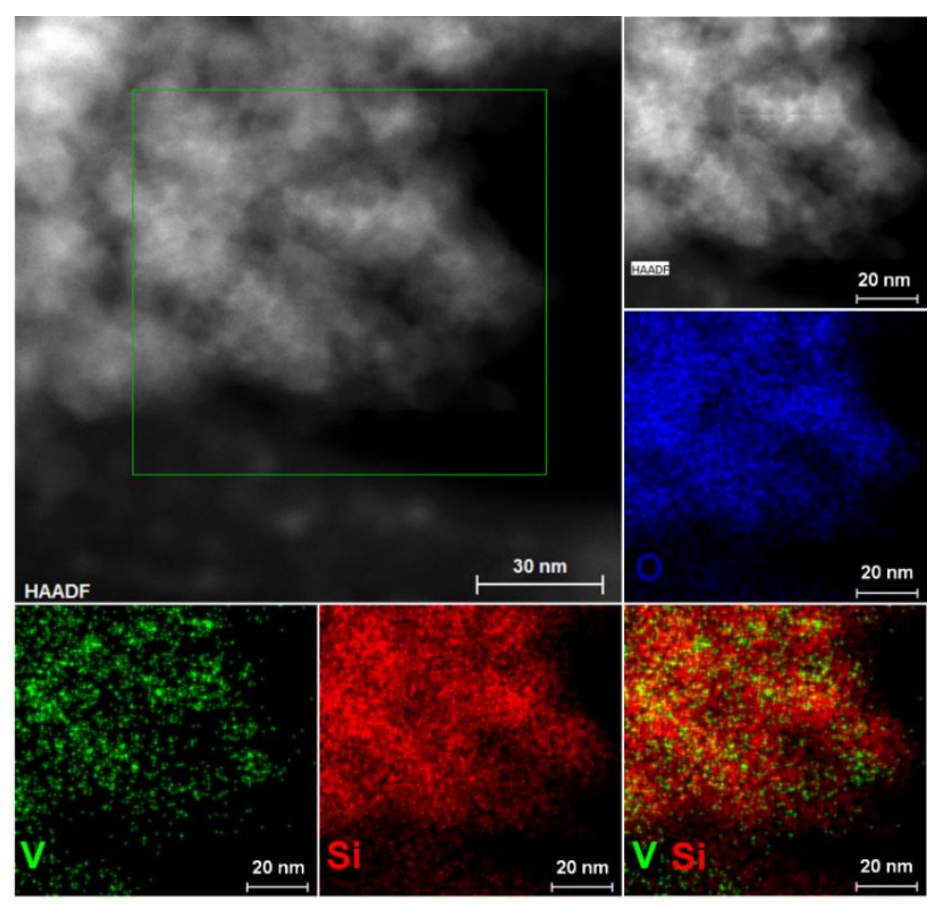

Figure S39. HR-TEM images and EDX mappings of $\left[\mathrm{VO}_{4}\right] / \mathrm{SiO}_{2}$ catalyst.

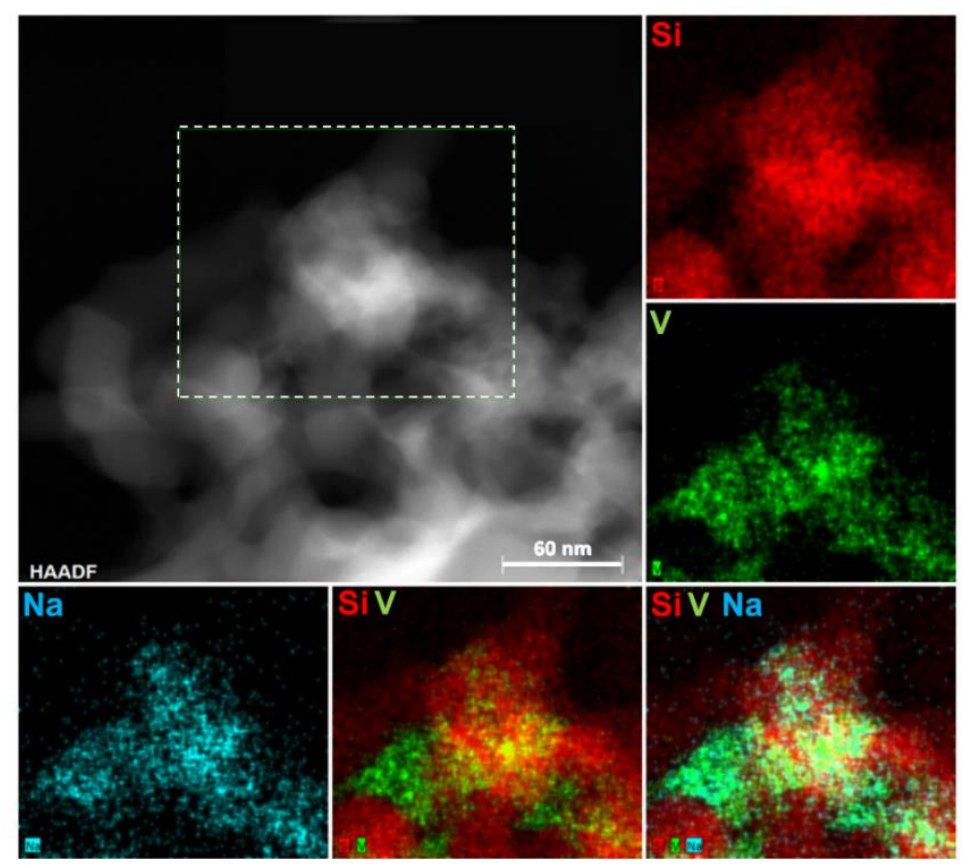

Figure S40. HR-TEM images and EDX mappings of $\alpha-\mathrm{NaVO}_{3} / \mathrm{SiO}_{2}$. 


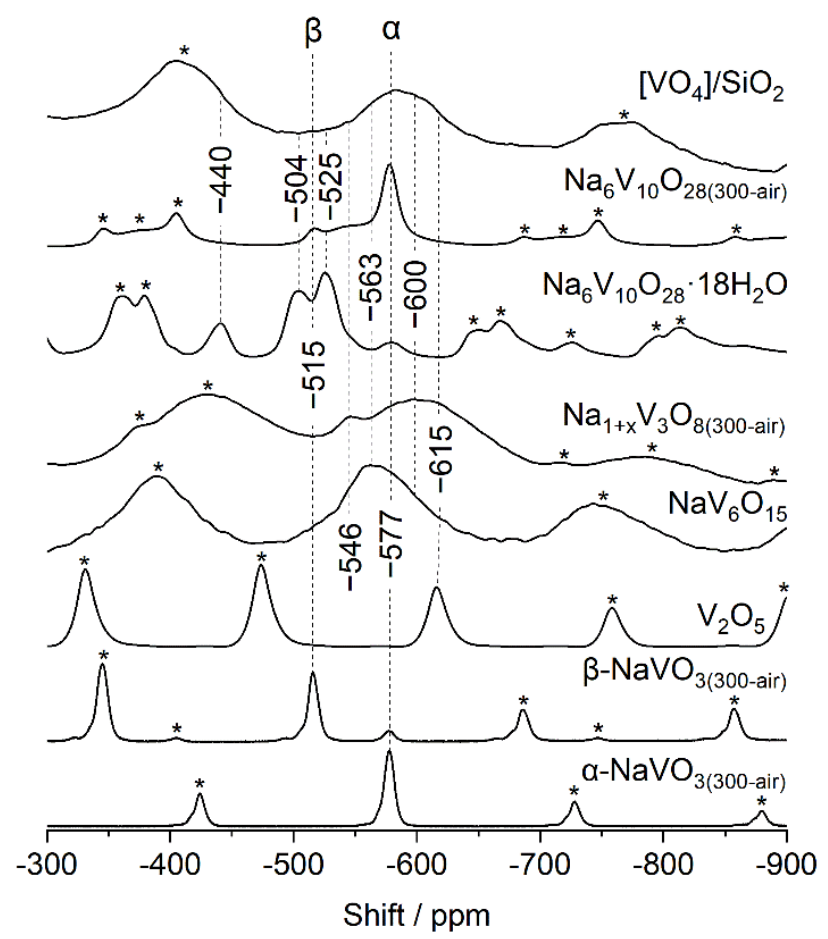

Figure S41. ${ }^{51} \mathrm{~V}$ MAS NMR spectra of materials reported in Table S1-2 that are not represented in the main text.

$15-18 \mathrm{kHz}$ spinning rates, sidebands are marked by asterisks. $\beta-\mathrm{NaVO}_{3}$ and $\mathrm{Na}_{1+\mathrm{x}} \mathrm{V}_{3} \mathrm{O}_{8}$ references contain minor amounts of $\mathrm{a}-\mathrm{NaVO}_{3}$ and $\mathrm{NaV}_{10} \mathrm{O}_{15}$ impurities, respectively

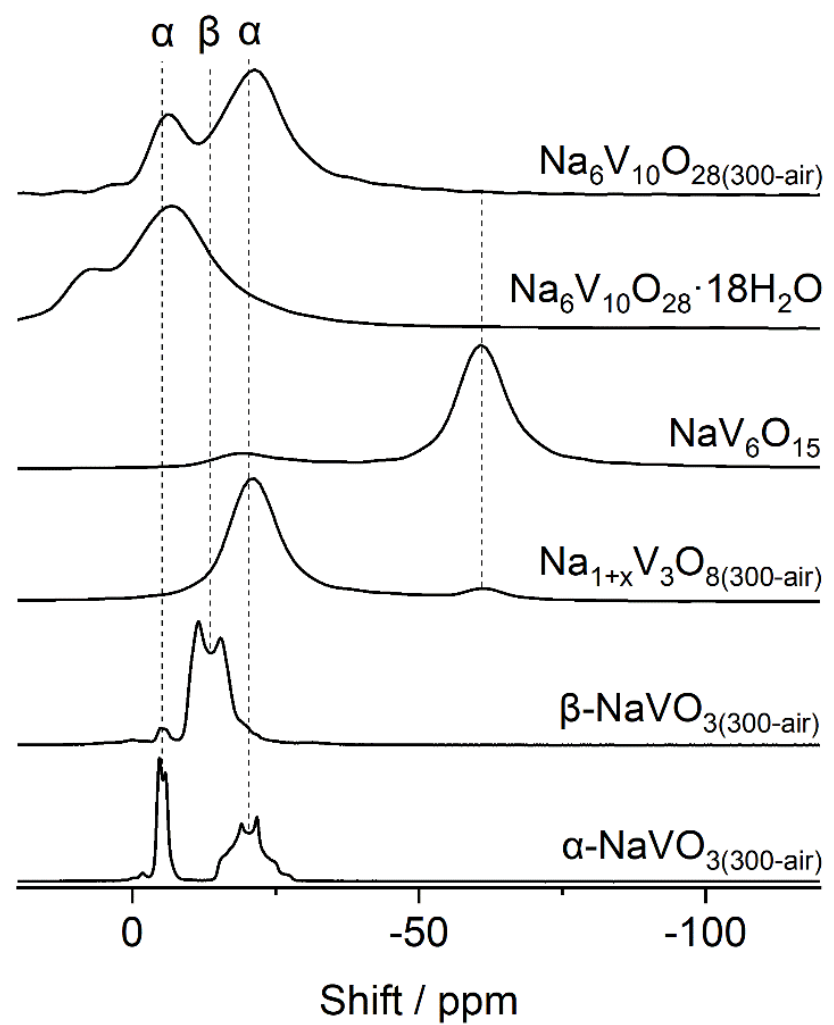

Figure S42. ${ }^{23} \mathrm{Na}$ MAS NMR spectra of materials reported in Table S1-2 that are not represented in the main text.

15-18 kHz spinning rates. $\beta-\mathrm{NaVO}_{3}$ and $\mathrm{Na}_{1+x} \mathrm{~V}_{3} \mathrm{O}_{8}$ references contain minor amounts of $\alpha-\mathrm{NaVO}_{3}$ and $\mathrm{NaV}_{10} \mathrm{O}_{15}$ impurities, respectively 
Table S1. Isotropic chemical shift $\left(\delta_{\text {iso }}\right)$, quadrupolar coupling constant $\left(\mathrm{C}_{\mathrm{Q}}\right)$, and quadrupolar asymmetry parameter $\left(\eta_{\mathrm{Q}}\right)$ for the materials studied under ambient conditions.

\begin{tabular}{|c|c|c|c|c|c|c|}
\hline Hydrated-material & Method & Site & $\mathrm{C}_{\mathrm{Q}} / \mathrm{MHz}$ & $\eta_{Q}$ & $\delta_{\text {iso }} / \mathrm{ppm}$ & Reference \\
\hline \multirow[t]{6}{*}{$\alpha-\mathrm{NaVO}_{3}$} & ${ }^{23} \mathrm{Na}$ MAS NMR & $\mathrm{Na}_{1}$ & 1.51 & 0.55 & -14.6 & This work \\
\hline & & $\mathrm{Na}_{2}$ & 0.78 & 0.06 & -3.9 & This work \\
\hline & & $\mathrm{Na}_{1}$ & $1.50 \pm 0.05$ & $0.58 \pm 0.02$ & $-15.6 \pm 0.5$ & [5] \\
\hline & & $\mathrm{Na}_{2}$ & $0.76 \pm 0.02$ & $0.06 \pm 0.02$ & $-4.8 \pm 0.2$ & [5] \\
\hline & ${ }^{51} \mathrm{~V}$ MAS NMR & v & - & - & -577 & This work \\
\hline & & $\mathrm{v}$ & - & - & -576 & [16] \\
\hline \multirow[t]{5}{*}{$\beta-\mathrm{NaVO}_{3}$} & ${ }^{23} \mathrm{Na}$ MAS NMR & $\mathrm{Na}$ & 1.44 & 0.25 & -8.9 & This work \\
\hline & & $\mathrm{Na}$ & $1.42 \pm 0.02$ & $0.27 \pm 0.02$ & $-10.3 \pm 0.3$ & [5] \\
\hline & ${ }^{51} \mathrm{~V}$ MAS NMR & $\mathrm{v}$ & - & - & -515 & This work \\
\hline & & $\mathrm{v}$ & $4.20 \pm 0.10$ & $0.55 \pm 0.04$ & $-510.4 \pm 0.5$ & [5] \\
\hline & & v & - & - & -516.4 & {$[17]$} \\
\hline \multirow[t]{7}{*}{$\mathrm{Na}_{6} \mathrm{~V}_{10} \mathrm{O}_{28} \cdot 18 \mathrm{H}_{2} \mathrm{O}$} & ${ }^{23} \mathrm{Na}$ MAS NMR & $\mathrm{Na}_{1-2}$ & - & - & $-6,7$ & This work \\
\hline & ${ }^{51} \mathrm{~V}$ MAS NMR & $V_{A}$ & - & - & -525 & This work \\
\hline & & $V_{B}$ & - & - & -504 & This work \\
\hline & & $v_{c}$ & - & - & -440 & This work \\
\hline & & $V_{1-4}$ & - & - & $-492,-505,-513,-535$ & {$[16]$} \\
\hline & ${ }^{51} \mathrm{~V}$ liquid state NMR & $V_{A \cdot c}$ & - & - & $-513,-498,-422$ & This work \\
\hline & & $V_{A \cdot c}$ & - & - & $-515,-500,-423$ & [6] \\
\hline \multirow[t]{2}{*}{$\mathrm{V}_{2} \mathrm{O}_{5}$} & ${ }^{51} \mathrm{~V}$ MAS NMR & v & - & - & -615 & This work \\
\hline & & v & - & - & -614 & [18] \\
\hline$\alpha^{\prime}-\mathrm{NaV}_{2} \mathrm{O}_{5}$ & ${ }^{23} \mathrm{Na}$ MAS NMR & $\mathrm{Na}$ & - & - & -48 & This work \\
\hline \multirow[t]{3}{*}[\mathrm{VO}_{4}]{$/ \mathrm{SiO}_{2}$} & ${ }^{51} \mathrm{~V}$ MAS NMR & v & - & - & -567 & [19] \\
\hline & & v & - & - & -575 & This work \\
\hline & & v & - & - & -580 & [20] \\
\hline \multirow[t]{2}{*}{$\mathrm{Na}_{1+\mathrm{x}} \mathrm{V}_{3} \mathrm{O}_{8}$} & ${ }^{51} \mathrm{~V}$ MAS NMR & $V_{1-3}$ & - & - & $-547,-577,-600$ & This work \\
\hline & ${ }^{23} \mathrm{Na}$ MAS NMR & $\mathrm{Na}_{1-2}$ & - & - & $-21,-61$ & This work \\
\hline \multirow[t]{2}{*}{$\mathrm{NaV}_{3} \mathrm{O}_{8} \cdot 1.5 \mathrm{H}_{2} \mathrm{O}$} & ${ }^{51} \mathrm{~V}$ MAS NMR & $\mathrm{V}_{\mathrm{a}}$ & $3.1 \pm 0.10$ & $0.9 \pm 0.1$ & $-548 \pm 1$ & [21] \\
\hline & & $\mathrm{V}_{\mathrm{b}}$ & $2.4 \pm 0.10$ & $0.8 \pm 0.1$ & $-535 \pm 1$ & [21] \\
\hline $\mathrm{Na}_{0.66} \mathrm{~V}_{2} \mathrm{O}_{5}$ & ${ }^{23} \mathrm{Na}$ MAS NMR & $\mathrm{Na}$ & - & - & -25 & [22] \\
\hline \multirow[t]{2}{*}{$\mathrm{NaV}_{6} \mathrm{O}_{15}$} & ${ }^{23} \mathrm{Na}$ MAS NMR & $\mathrm{Na}$ & - & - & -61.9 & [22] \\
\hline & & $\mathrm{Na}$ & - & - & -60 & This work \\
\hline $\mathrm{NaV}_{6} \mathrm{O}_{15}$ & ${ }^{51} \mathrm{~V}$ MAS NMR & v & - & - & -563 & This work \\
\hline
\end{tabular}


Table S2. Isotropic chemical shift $\left(\delta_{\text {iso }}\right)$, quadrupolar coupling constant $\left(C_{Q}\right)$, and quadrupolar asymmetry parameter $\left(\eta_{Q}\right)$ for the materials studied under dehydrated conditions. Samples were dehydrated either at $300{ }^{\circ} \mathrm{C}$ or $500{ }^{\circ} \mathrm{C}$, specified with a subscript note, for $1 \mathrm{~h}$ in a fixed bed quartz reactor under $30 \mathrm{ml} \mathrm{min}^{-1}$ air or $\mathrm{N}_{2}$ flow and then cooled down under air or $\mathrm{N}_{2}$ and switched to nitrogen at room temperature $\left(30 \mathrm{ml} \mathrm{min}^{-1}\right)$. Samples were packed into rotors inside a nitrogen-filled glovebox $(<0.5 \mathrm{ppm}$ of $\mathrm{O}_{2}$ and $\mathrm{H}_{2} \mathrm{O}$ ).

\begin{tabular}{|c|c|c|c|c|c|c|}
\hline Dehydrated material & Method & Site & $\mathrm{C}_{Q} / \mathrm{MHz}$ & $\eta_{a}$ & $\delta_{\text {iso }} / \mathrm{ppm}$ & Reference \\
\hline \multirow[t]{3}{*}{$\alpha-\mathrm{NaVO}_{3(300-\text {-air })}$} & ${ }^{23} \mathrm{Na}$ MAS NMR & $\mathrm{Na}_{1}$ & 1.51 & 0.56 & -14.6 & This work \\
\hline & & $\mathrm{Na}_{2}$ & 0.79 & 0.33 & -3.8 & This work \\
\hline & ${ }^{51} \mathrm{~V}$ MAS NMR & v & - & - & -577 & This work \\
\hline \multirow[t]{2}{*}{$\beta-\mathrm{NaVO}_{3(300 \text {-air) }}$} & ${ }^{23} \mathrm{Na}$ MAS NMR & $\mathrm{Na}$ & 1.45 & 0.22 & -8.9 & This work \\
\hline & ${ }^{51} \mathrm{~V}$ MAS NMR & v & - & - & -515 & This work \\
\hline \multirow[t]{2}{*}{$\mathrm{Na}_{1+\mathrm{x}} \mathrm{V}_{3} \mathrm{O}_{8(300 \text {-air })}$} & ${ }^{23} \mathrm{Na}$ MAS NMR & $\mathrm{Na}_{1-2}$ & & & $-21,-61$ & This work \\
\hline & ${ }^{51} \mathrm{~V}$ MAS NMR & $V_{1-2}$ & & & $-546,-600$ & This work \\
\hline \multirow[t]{2}{*}{$\mathrm{Na}_{6} \mathrm{~V}_{10} \mathrm{O}_{28 \text { (300-air) }}$} & ${ }^{23} \mathrm{Na}$ MAS NMR & $\mathrm{Na}_{1-2}$ & - & - & $-6,-21$ & This work \\
\hline & ${ }^{51} \mathrm{~V}$ MAS NMR & $V_{1-3}$ & - & - & $-516,-576,-546$ & This work \\
\hline \multirow[t]{2}{*}{$\alpha-\mathrm{NaVO}_{3} / \mathrm{SiO}_{2(500-\text { air) }}$} & ${ }^{23} \mathrm{Na}$ MAS NMR & $\mathrm{Na}_{1-2}$ & - & - & $-8,-23$ & This work \\
\hline & ${ }^{51} \mathrm{~V}$ MAS NMR & v & - & - & -578 & This work \\
\hline \multirow[t]{2}{*}{$\mathrm{Na}_{6} \mathrm{~V}_{10} \mathrm{O}_{28} / \mathrm{SiO}_{2(500-\text { air })}$} & ${ }^{23} \mathrm{Na}$ MAS NMR & $\mathrm{Na}_{1-2}$ & - & - & $-16,-29$ & This work \\
\hline & ${ }^{51} \mathrm{~V}$ MAS NMR & $V_{1-4}$ & - & - & $-515,-547,-577,-600$ & This work \\
\hline \multirow[t]{2}{*}{$\mathrm{Na}_{6} \mathrm{~V}_{10} \mathrm{O}_{28} / \mathrm{SiO}_{2(500-\mathrm{N} 2)}$} & ${ }^{23} \mathrm{Na}$ MAS NMR & $\mathrm{Na}_{1-3}$ & & & $-24,-31,-46$ & This work \\
\hline & ${ }^{51} \mathrm{~V}$ MAS NMR & v & & & -615 & This work \\
\hline \multirow[t]{3}{*}[\mathrm{VO}_{4}]{$/ \mathrm{SiO}_{2(500 \text {-air) }}$} & ${ }^{51} \mathrm{~V}$ MAS NMR & v & - & - & -710 & This work \\
\hline & & v & - & - & $-710 \pm 10$ & [23] \\
\hline & & v & - & - & -694 & [24] \\
\hline \multirow[t]{2}{*}{$\mathrm{Na}_{1+\mathrm{x}} \mathrm{V}_{3} \mathrm{O}_{8} / \mathrm{SiO}_{2(500 \text {-air) }}$} & ${ }^{23} \mathrm{Na}$ MAS NMR & $\mathrm{Na}_{1-2}$ & & & $-16,-27$ & This work \\
\hline & ${ }^{51} \mathrm{~V}$ MAS NMR & V & - & - & -615 & This work \\
\hline
\end{tabular}




\section{References}

[1] Brunauer, S.; Emmett, P. H.; Teller, E., Adsorption of Gases in Multimolecular Layers. J. Am. Chem. Soc. 1938, 60, 309-319.

[2] Barrett, E. P.; Joyner, L. G.; Halenda, P. P., The Determination of Pore Volume and Area Distributions in Porous Substances. I. Computations from Nitrogen Isotherms. J. Am. Chem. Soc. 1951, 73, 373-380.

[3] Ravel, B.; Newville, M., ATHENA, ARTEMIS, HEPHAESTUS: data analysis for X-ray absorption spectroscopy using IFEFFIT. J. Synchrotron Radiat. 2005, 12, 537-541.

[4] Seetharaman, S.; Bhat, H. L.; Narayanan, P. S., Raman spectroscopic studies on sodium metavanadate. J. Raman Spectrosc. $1983,14,401-405$.

[5] Skibsted, J.; Nielsen, N. C.; Bildsoe, H.; Jakobsen, H. J., Magnitudes and relative orientation of ${ }^{51} \mathrm{~V}$ quadrupole coupling and anisotropic shielding tensors in metavanadates and potassium vanadium oxide $\left(\mathrm{KV}_{3} \mathrm{O}_{8}\right)$ from ${ }^{51} \mathrm{~V}$ MAS NMR spectra. ${ }^{23} \mathrm{Na}$ quadrupole coupling parameters for $\alpha$ - and $\beta$ $\mathrm{NaVO}_{3}$. J. Am. Chem. Soc. 1993, 115, 7351-7362.

[6] Domaille, P. J., The 1- and 2-dimensional tungsten-183 and vanadium-51 NMR characterization of isopolymetalates and heteropolymetalates. J. Am. Chem. Soc. 1984, 106, 7677-7687.

[7] a) Hartung, S.; Bucher, N.; Chen, H.-Y.; Al-Oweini, R.; Sreejith, S.; Borah, P.; Yanli, Z.; Kortz, U.; Stimming, U.; Hoster, H. E.; Srinivasan, M. Vanadium-based polyoxometalate as new material for sodium-ion battery anodes. J. Power Sources 2015, 288, 270-277; b) Chen, H.-Y.; Wee, G.; Al-Oweini, R.; Friedl , J.; Tan, K. S.; Wang, Y.; Wong , C. L.; Kortz, U.; Stimming, U.; Srinivasan, M., A Polyoxovanadate as an Advanced Electrode Material for Supercapacitors. ChemPhysChem 2014, 15, 2162-2169; c) Deo, G.; Wachs, I. E. Predicting molecular structures of surface metal oxide species on oxide supports under ambient conditions. J. Phys. Chem. 1991, 95, 5889-5895.

[8] Heath, E.; Howarth, O. W., Vanadium-51 and oxygen-17 nuclear magnetic resonance study of vanadate (V) equilibria and kinetics. J. Chem. Soc. Dalton Trans. 1981, 1105-1110.

[9] Ramos, S.; Duarte, R. O.; Moura, J. J. G.; Aureliano, M., Decavanadate interactions with actin: cysteine oxidation and vanadyl formation. Dalton Trans. 2009, 7985-7994

[10] Liu, P.; Zhou, D.; Zhu, K.; Wu, Q.; Wang, Y.; Tai, G.; Zhang, W.; Gu, Q. Bundle-like $\alpha^{\prime}-\mathrm{NaV}_{2} \mathrm{O}_{5}$ mesocrystals: from synthesis, growth mechanism to analys is of $\mathrm{Na}$-ion intercalation/deintercalation abilities. Nanoscale 2016, 8, 1975-1985.

[11] a) Hu, F.; Ming, X.; Chen, G.; Wang, C.; Li, A.; Li, J.; Wei, Y. Synthesis and characterizations of highly crystallized $\alpha^{\prime}-N_{2} V_{2} \mathrm{O}_{5}$ needles prepared by a hydrothermal process. J. Alloys Compd. 2009, 479, 888-892; b) Popović, Z. V.; Konstantinović, M. J.; Gajić, R.; Popov, V.; Raptis, Y. S.; Vasil'ev, A. N.; Isobe, M.; Ueda, Y. Lattice vibrations in spin-Peierls compound $\mathrm{NaV}_{2} \mathrm{O}_{5}$. Solid State Commun. 1999, 110, $381-386$.

[12] Kang, H.; Liu, Y.; Shang, M.; Lu, T.; Wang, Y.; Jiao, L., $\mathrm{NaV}_{3} \mathrm{O}_{8}$ nanosheet@polypyrrole core-shell composites with good electrochemical performance as cathodes for Na-ion batteries. Nanoscale 2015, 7, 9261-9267.

[13] Zhang, X.; Frech, R., Spectroscopic investigation of $\mathrm{Li}_{1+\mathrm{x}} \mathrm{V}_{3} \mathrm{O}_{8}$. Electrochim. Acta 1998, 43, 861-868.

[14] Nair, V. S.; Cheah, Y. L.; Madhavi, S., Symmetric Aqueous Rechargeable Lithium Battery Using $\mathrm{Na}_{1.16} \mathrm{~V}_{3} \mathrm{O}_{8} \mathrm{Nanobelts}$ Electrodes for Safe High Volume Energy Storage Applications. J. Electrochem. Soc. 2014, 161, A256-A263.

[15] Chen, H.-Y.; Wee, G.; Al-Oweini, R.; FriedI, J.; Tan, K. S.; Wang, Y.; Wong, C. L.; Kortz, U.; Stimming, U.; Srinivasan, M. A Polyoxovanadate as an Advanced Electrode Material for Supercapacitors. ChemPhysChem 2014, 15, 2162-2169.

[16] Eckert, H.; Wachs, I. E., Solid-state vanadium-51 NMR structural studies on supported vanadium (V) oxide catalysts: vanadium oxide surface layers on alumina and titania supports. J. Phys. Chem. A 1989, 93,6796-6805.

[17] Hayashi, S.; Hayamizu, K., ${ }^{51}$ V NMR chemical shift and anisotropy in solid metavanadates. Bull. Chem. Soc. Jpn. 1990, 63, 961-963. [18] Grant, J. T.; Carrero, C. A.; Love, A. M.; Verel, R.; Hermans, I., Enhanced Two-Dimensional Dispersion of Group V Metal Oxides on Silica. ACS Catal.
2015, 5, 5787-5793. Jaegers, N. R.; Wan, C.; Hu, M. Y.; Vasiliu, M.; Dixon, D. A.; Walter, E.; Wachs, I. E.; Wang, Y.; Hu, J. Z. Investigation of Silica-Supported Vanadium

[20] Oxide Catalysts by High-Field ${ }^{51} \mathrm{~V}$ Magic-Angle Spinning NMR. J. Phys. Chem. C 2017, 121, 6246-6254. of propane. J. Catal. 2010, 274, 64-75.

[21] Durupthy, O.; Steunou, N.; Coradin, T.; Maquet, J.; Bonhomme, C.; Livage, J. Influence of pH and ionic strength on vanadium(v) oxides formation From $\mathrm{V}_{2} \mathrm{O}_{5} \cdot \mathrm{nH}_{2} \mathrm{O}$ gels to crystalline $\mathrm{NaV}_{3} \mathrm{O}_{8} \cdot 1.5 \mathrm{H}_{2} \mathrm{O}$. J. Mater. Chem. 2005, 15, 1090-1098.

[22] Terskikh, V. V.; Lapina, O. B.; Bondareva, V. M. Sodium-modified $\mathrm{V}_{2} \mathrm{O}_{5}-\mathrm{TiO}_{2}$ catalysts: ${ }^{23} \mathrm{Na}$ and ${ }^{51} \mathrm{~V}$ solid-state NMR study. Phys. Chem. Chem. Phys. 2000, 2, 2441-2448

[23] Das, N.; Eckert, H.; Hu, H.; Wachs, I. E.; Walzer, J. F.; Feher, F. J., Bonding states of surface vanadium(V) oxide phases on silica: structural characterization by vanadium-51 NMR and Raman spectroscopy. J. Phys. Chem. 1993, 97, 8240-8243.

[24] Love, A. M.; Carrero, C. A.; Chieregato, A.; Grant, J. T.; Conrad, S.; Verel, R.; Hermans, I., Elucidation of Anchoring and Restructuring Steps during Synthesis of Silica-Supported Vanadium Oxide Catalysts. Chem. Mater. 2016, 28, 5495-5504. 